\title{
Financial disincentives to formal employment and tax-benefit systems in Latin America
}

\section{H. Xavier Jara ${ }^{1} \mathbb{D} \cdot$ María Cecilia Deza Delgado ${ }^{2} \cdot$ Nicolás Oliva $^{3} \cdot$ Javier Torres $^{4}$}

Accepted: 17 December 2021 / Published online: 2 February 2022

(c) The Author(s) 2022

\begin{abstract}
The aim of this paper is twofold. First, it provides a comprehensive assessment of the financial disincentives to enter formal employment implied by the design of the taxbenefit system in five Latin American countries: Bolivia, Colombia, Ecuador, Peru, and Venezuela. Then, it analyzes the extent to which formalizing informal workers would contribute to increase fiscal capacity in the region. The results show a wide variation in financial disincentives to enter formal employment, with formalization tax rates ranging between 8.5 percent in Venezuela and 42 percent in Colombia. Formalization tax rates are particularly high for self-employed informal workers, and mainly driven by the high costs associated with social insurance contributions. The analysis further shows that potential entries to formal employment would raise tax revenue in all countries, but mainly through the effect of increased social insurance contributions, whereas personal income tax revenue would have a marginal contribution, except in Bolivia and Venezuela. Interestingly, potential formalization of informal workers with the highest probability of being formal would allow capturing a substantial share of the additional tax revenue lost due to informality.
\end{abstract}

Keywords Taxes $\cdot$ Informality $\cdot$ Fiscal capacity $\cdot$ Inequality $\cdot$ Microsimulation

JEL Classification D13 $\cdot \mathrm{H} 24 \cdot \mathrm{I} 32 \cdot \mathrm{I} 38$

H. Xavier Jara

hxjara@essex.ac.uk

1 Institute for Social and Economic Research (ISER), University of Essex, Colchester, UK

2 Inter-American Development Bank, Washington DC, USA

3 Universitat Autònoma de Barcelona, Barcelona, Spain

4 Universidad del Pacífico, Lima, Peru 


\section{Introduction}

Tax revenue in countries in the Latin American and Caribbean (LAC) region remains low compared with developed economies. In 2015, the average tax-to-GDP ratio was 22.8 percent for the entire region and up to 34.3 percent on average for OECD countries (OECD et al., 2017). These differences can be partially explained by the lower contribution of income taxes to total tax revenue. In 2015, taxes on income and profits represented 27 percent of total tax revenue in the LAC region compared to 33.7 percent in OECD countries. Moreover, in 2014, the share of personal income tax was extremely low in LAC countries compared to personal income tax in OECD countries, at 8.7 and 24 percent, respectively. The literature has pointed to three main drivers explaining the region's modest personal income tax contribution: high levels of informality (OECD et al., 2021), the generosity of thresholds for which income is exempted from tax payments, and the presence of generous tax deductions (IDB, 2013). For instance, the income needed to reach the personal income tax brackets represents 0.24 of the income per capita in OECD countries and 1.4 times the income per capita in Latin American Countries. The income needed to reach the highest tax threshold represents 2.38 and 9.1 times of the income per capita in OECD countries and Latin American countries, respectively. Additionally, it is estimated that the region of Latin America sacrifices about 1 percent of GDP in personal income tax revenues due to tax expenditures (IDB, 2013).

The aim of this paper is twofold. First, it provides a comprehensive assessment of the financial cost informal workers would incur if they entered formal employment in five countries in the Andean region: Bolivia, Colombia, Ecuador, Peru, and Venezuela. Financial disincentives to formal employment are measured by formalization tax rates (FTRs), which capture the percentage of earnings in informality that would be lost due to increased social insurance contributions and income tax payments or benefit withdrawal upon entry to formal employment. Then, it analyzes the extent to which formalizing informal workers would contribute to increase fiscal capacity in the region - at a time when fiscal budgets are under pressure - and assesses the distributional implications of counterfactual entries to formal employment. The analysis makes use of multi-country tax-benefit microsimulation models based on nationally representative household survey data: COLMOD (Colombia), ECUAMOD (Ecuador), PERUMOD (Peru), and LATINMOD (Bolivia and Venezuela). The models have been developed within the EUROMOD framework to ensure cross-country comparability through data and modeling language harmonization (Sutherland \& Figari, 2013). The countries under analysis share a number of similar features. They had similar standards of living proxied by GDP per capita in the year under analysis (i.e., 2015). They are all commodity exporters and characterized by volatile revenues and growth. Andean countries have the highest informality rates in the LAC region.

Our results show a wide variation in financial disincentives to enter formal employment implied by the tax-benefit system, with FTRs ranging between 8.5 and 42 percent (in Venezuela and Colombia, respectively). These rates are particularly high for self-employed informal workers with low earnings in all five countries and 
are mainly driven by high costs associated with social insurance contribution payments for this group, due to the requirement that social insurance contributions are paid at least on the basis of the national minimum wage. Our simulations of counterfactual entries to formal employment show that the potential to increase social insurance contributions revenue would be substantial under a fully formalized economy. The additional revenue from personal income tax would be high in Bolivia and Venezuela, whereas the effect of a fully formalized economy would be limited in this respect in Colombia, Ecuador, and Peru. Interestingly, our results show that a formalization of informal workers with the highest probability of being formal (i.e., 10 percent of the total informal workers) would enable to capture a substantial share of the additional tax revenue lost due to informality. This group of workers generally face low FTRs, and their potential entry to formal employment would have a positive effect in inequality reduction due to an increased redistributive effect of personal income tax.

The work herein contributes to the literature on potential factors influencing workers' decisions to enter formal employment, with a strong focus on the role of the design of the tax-benefit system as a whole. From a policy perspective, understanding the incentives to formal employment inherent to this system is essential to implement formalization strategies aimed at increasing fiscal capacity and providing long-term social protection to workers. Cross-country comparative analysis offers the additional advantage of learning from the design of different tax-benefit policies to consider potential reforms aimed at creating incentives to formalization. Our work also contributes to the literature discussing the link between informality and low tax revenue. In particular, contrary to the general idea that informality constrains tax collection (OECD et al., 2021), our results show that the additional tax revenue from personal income tax would be marginal even under a scenario of a fully formalized labor force, due to the current design of personal income tax in the countries under study.

The paper is organized as follows. Section 2 provides a brief overview of informal employment in the five Andean countries. Section 3 presents the models and data used in the analysis. Section 4 presents the results of our empirical analysis, and Sect. 5 concludes with a discussion of policy implications.

\section{Informal employment in Latin America}

This section provides an overview of the definition and causes of labor informality, followed by a review of the extent to which labor markets in the countries under study are affected by the presence of informal employment. 


\subsection{Brief review of informal employment}

High and persistent labor informality has been a major problem for developing countries, especially those in the LAC region, where, on average, 60 percent of the labor force works in the informal sector (IDB, 2018). ${ }^{1}$ In the countries under analysis in particular, informal employment accounts for 70 percent of total employment on average. ${ }^{2}$ A similar phenomenon is observed in terms of firm informality (La Porta $\&$ Shleifer, 2014), ${ }^{3}$ which accounts for half of the economic activity. The incidence of informality is one of the most persistent, negative, and worrisome characteristics of the labor markets in the LAC region, where about 140 million of the 263 million workers work in the informal market.

To study labor informality, it is important to understand the origin of its definition. The concept first appeared in 1972 in a publication describing the employment situation in Kenya (Guerguil, 1988; ILO, 1972), ${ }^{4}$ and since then, there have been many other published definitions (see Perry et al., 2007). In general, all definitions can be summarized in two main approaches used by the International Labour Organization. The first is the productivity view, which defines informality according to the characteristics of the firm - usually the size - where the individual works. Small firms are considered to be of low productivity and therefore part of the informal sector. $^{5}$ The second is the legalistic view, which characterizes informal workers as those without access to the social security or pension systems (Saavedra \& Chong, 1999). ${ }^{6}$ This paper uses the legalistic view-non-affiliation to any type of social security regime- to define labor informality, as information about affiliation to social security is reported in the data used in the analysis.

The causes of labor informality are widely argued in the pertinent literature. Some works claim that informal firms provide refuge for the poor against excessive government regulations (De Soto, 2000), while other authors look at the informal employment activity as a way of avoiding taxes and regulations, for both workers and firms (Levy, 2008). Another point of view is that informality is correlated

\footnotetext{
${ }^{1}$ According to the IDB's definition of labor informality, informal workers are those who do not contribute to social security (e.g., old-age pensions and health insurance). Specifically, informality is defined as the percentage of employed workers not contributing to old-age pensions. For a more detailed discussion, see Alaimo et al. (2016) and Bosch et al. (2013).

${ }^{2}$ Based on the average for 2018 (see the IDB Database: Labor Markets and Social Security Information System, available at https://www.iadb.org/en/sector/social-investment/sims/home).

${ }^{3}$ Different perspectives can be applied to the study of firm informality. One of the most common approaches relates informality to the size of the firm (in terms of workers), while others relate it to the incorporation of a firm as a legal entity; see Levy (2018) for a discussion on firm informality in Mexico. Another perspective comes from La Porta and Shleifer (2008), who define informal firms as those that are not registered with the government.

${ }^{4}$ In the LAC region, the concept of the informal sector was first promoted by the Regional Employment Program in Latin America and the Caribbean (PREALC) of the International Labor Organization.

${ }^{5}$ La Porta and Shleifer (2008) analyze the size and productivity of formal and informal firms in poor countries, finding that an average formal firm employs 126 people, while an average informal firm employs only 4.

${ }^{6}$ These two views of labor informality can overlap but do not necessarily cover the same set of workers in the informal sector (Gasparini \& Tornarolli, 2009).
} 
Table 1 Evolution of informal employment in the Andean region, 2007-18 (in percent of workers). Source Authors' elaboration using information from the IDB's labor market and social security information system, available at https://www.iadb.org/en/sector/social-investment/sims/home, which is based on official household surveys

\begin{tabular}{lllll}
\hline & 2007 & 2010 & 2015 & 2018 \\
\hline Bolivia & 85.4 & n.d & 81.1 & 79.7 \\
Colombia & 66.8 & 68.5 & 62.3 & 61.1 \\
Ecuador & 72.8 & 64.8 & 53.4 & 58.4 \\
Peru & 84.0 & 82.8 & 79.0 & 78.2 \\
Venezuela $^{\mathrm{a}}$ & 65.7 & 63.2 & 61.4 & $\mathrm{NA}$ \\
\hline
\end{tabular}

a2015 data correspond to 2014

with poverty (Harris \& Todaro, 1970; Rauch, 1991). These studies show differences between the formal and informal firms, where formal entrepreneurs usually have higher education levels, run larger businesses, and are able to pay taxes and adhere to government regulation, with the benefits of increasing customers, raising capital, and accessing public goods, among others. In contrast, informal entrepreneurs tend to have lower education levels, run smaller businesses, and have less productivity.

Regardless of the causes, in general, informality and low productivity are closely associated and put both workers and firms in a vicious circle that is difficult to overcome without a comprehensive public policy strategy. In such vicious circle, low productivity workers, usually self-employed, earn too little to even consider formalization as a viable option. Complementarily, if the benefits of operating in the formal sector are not perceived as valuable, incentives to formalization are further reduced. In this scenario, active formalization policies should follow a holistic approach, reducing labor costs to foster demand of low-income workers, increasing the perceived benefits in the eyes of employees and firms, and boosting labor productivity with reforms in sectors such as education, health, infrastructure, and innovation.

\subsection{Informal employment in the countries under study}

Since 2007, LAC countries have experienced decreasing rates of labor informality (Salazar-Xirinachs \& Chacaltana, 2018). However, the evolution shows heterogeneity among countries due to the implementation of different formalization policies (ILO, 2014). Among the countries under study, Ecuador has had a marked reduction in informality (14 percentage points between 2007 and 2018) as a result of active formalization policies and employment surveillance, whereas decreases in Bolivia, Colombia, and Peru have been lower (about 6 percentage points in the same period) (Table 1). Venezuela's evolution is harder to portray due to a lack of data for the most recent years.

Figure 1 provides additional information about the characteristics of informal employment in Bolivia, Colombia, Ecuador, and Peru in 2018, specifically comparing firm size, gender ratio, and quintiles of labor income. 

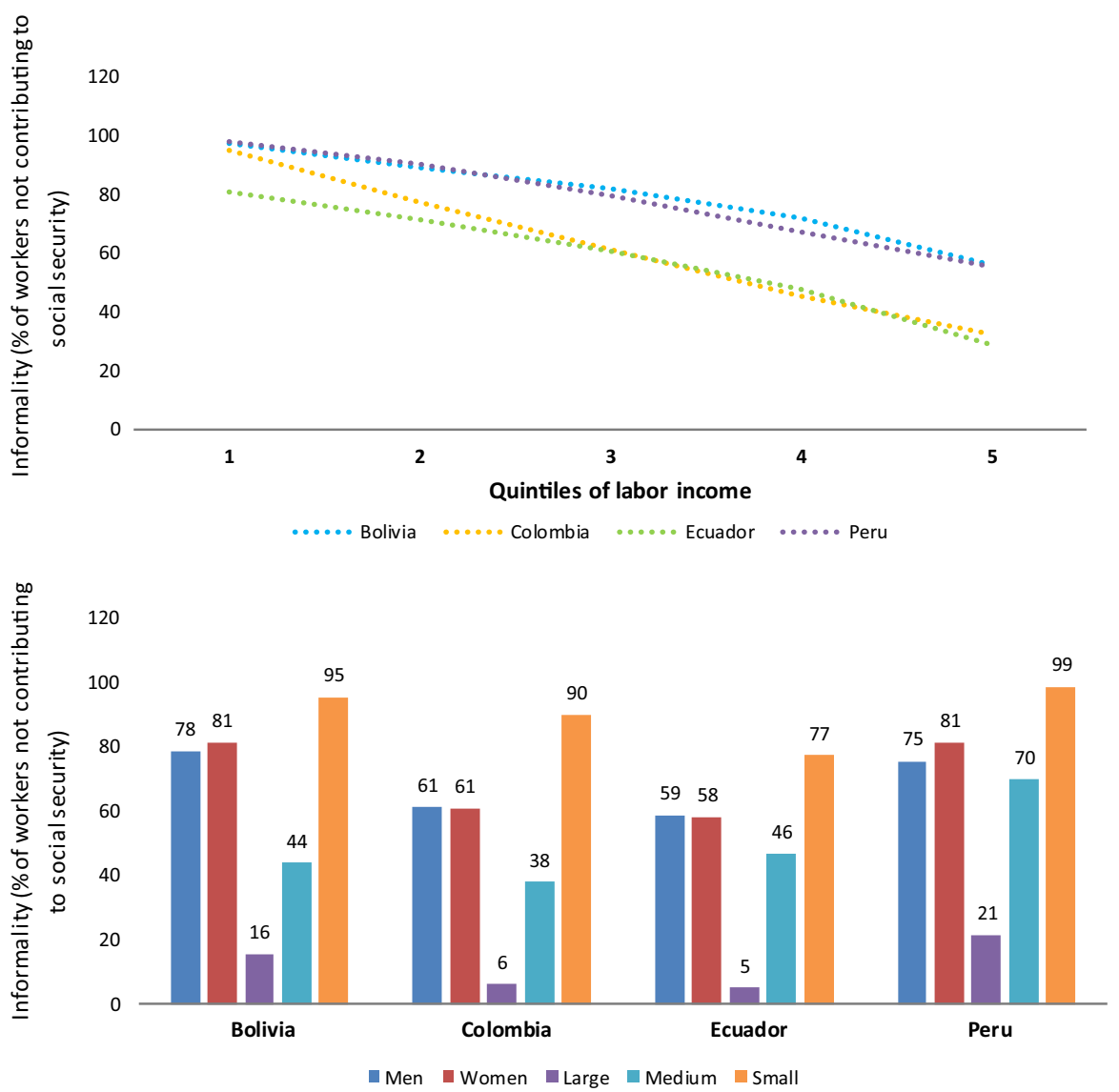

Fig. 1 Characteristics of informal employment, 2018 (in percent of workers). Source Authors' elaboration using information from the IDB's labor market and social security information system, available at https://www.iadb.org/en/sector/social-investment/sims/home, which is based on official household surveys. Note Data for Venezuela are not available

As expected, informality was higher among employees of small firms, especially in Peru and Bolivia, while in larger firms, incidences were between 5 and 20 percent. Informality was higher among female workers in Bolivia and Peru, equal in Colombia, and lower in Ecuador. Finally, informality was negatively associated with labor income, as expected. Informality was strikingly high in the first quintile of labor income, ranging between 80 and 100 percent, compared to 30-60 percent in the top quintile of the distribution of labor income. 
Table 2 Informality rates by employment status in the countries under analysis. Source Authors' elaboration based on household surveys

\begin{tabular}{llllll}
\hline & Bolivia & Colombia & Ecuador & Peru & Venezuela \\
\hline Employees & 42.2 & 38.8 & 44.3 & 49.3 & 58.6 \\
Self-employed & 89.3 & 88.7 & 84.7 & 81.6 & 90.2 \\
\hline
\end{tabular}

\section{Methodology}

The analysis makes use of tax-benefit microsimulation models for Latin American countries, based on nationally representative household survey data. The models are harmonized computer programs performing the computation of taxes and social contribution paid, and benefits received, by each household in the underlying data depending on its income and demographic characteristics.

\subsection{Data and microsimulation models}

Data Our results are based on nationally representative household survey data from Bolivia, Colombia, Ecuador, Peru, and Venezuela. The data sources used in the analysis are summarized in Table 3. All surveys contain detailed information on household and personal characteristics, employment, earnings, income from capital and property, private transfers, cash transfers, pensions, and expenditures. Income concepts have been harmonized in all datasets to achieve comparability in the simulation results (see Jara et al., 2019 and Rodriguez et al., 2019). Importantly, all surveys contain information about affiliation to social security, which we use to define informal employment. ${ }^{7}$ More precisely, informal employment is defined as work without affiliation to social security. ${ }^{8}$

Table 2 provides information about informality rates for employees and selfemployed workers in our data. Informal employment is strikingly high among selfemployed workers in all countries, and particularly so in Bolivia, Colombia and Venezuela, where informality rates are above 85 percent. Informal employment is less prevalent among employees but still high, ranging between 38.8 percent in Colombia and 58.6 percent in Venezuela.

Figure 11 in Appendix B presents the distribution of earnings for formal (blue distributions) and informal (gray distributions) workers, distinguishing between employees and the self-employed. In all countries, the earnings distributions of

\footnotetext{
7 The surveys used in the analysis are the official sources to track the evolution of household incomes and expenditures in each country and information about non-affiliation to social security is consistent with official labor force surveys.

8 Note that in Ecuador and Venezuela self-employed social insurance contributions are not mandatory, therefore, the denomination of "informal workers" for self-employed non-affiliated to social security might not be totally fitting. However, the overall aim of the paper still holds, as we are interested in assessing the costs these workers would face if they were affiliated to social security.
} 
formal workers are shifted to the right compared with those of informal workers, for both employees and the self-employed. The only exceptions are for selfemployed workers in Ecuador and Venezuela, where the distributions of informal and formal workers broadly overlap with very similar median incomes (dashed vertical lines). The results for Ecuador and Venezuela are consistent with the design of self-employed social insurance contributions, which are not mandatory for this category of workers. The Figure further shows that there is a high proportion of self-employed informal workers with earnings below the minimum wage (vertical red line), ranging from 28 percent in Venezuela up to 71 percent in Colombia. The proportion of informal employees with earnings below the minimum wage ranges from 9 percent in Venezuela to 54 percent in Colombia.

As discussed below, our approach to measure formalization costs for workers, and the budgetary and distributional effects of formalization, consists of simulating transitions from informal to formal employment in our data. Our selected sample for the simulated transitions is composed of all informal workers aged between 18 and 60 , excluding full-time students or retirees and those earning less than US\$1.9 per day. The latter restriction is imposed to consider only informal workers who might potentially enter formal employment and is in line with the literature on subsistence self-employment in the developing world, where low-productivity workers engage in informal self-employment activities to ensure a minimum level of subsistence, due to the lack of better alternatives (Margolis, 2014). Table 12 in Appendix B presents descriptive statistics for our sample of analysis.

Tax-benefit models Our analysis makes use of harmonized, tax-benefit microsimulation models for Latin American countries based on nationally representative household survey data: COLMOD (Colombia), ECUAMOD (Ecuador), PERUMOD (Peru), and LATINMOD (Bolivia and Venezuela). ${ }^{9}$ Tax-benefit microsimulation combines country-specific coded policy rules with representative household microdata to simulate direct taxes, social insurance contributions, and cash transfers for the household population in each country. More precisely, information about market incomes and sociodemographic characteristics of households from the microdata is taken as input in the models for the simulation of tax-benefit instruments, following as closely as possible the policy rules of each instrument according to the national legislation. All models are static in the sense that tax-benefit simulations abstract from individuals' behavioral reactions and no adjustments are made for changes in the population composition over time. Table 3 summarizes the information about

\footnotetext{
9 The model for Ecuador, ECUAMOD, has been developed and is maintained as part of the SOUTHMOD project. For more information see Jara and Varela (2019) and https://www.wider.unu.edu/ project/southmod-simulating-tax-and-benefit-policies-development. The model for Colombia, COLMOD, is developed and maintained by the Faculty of Economics at Universidad Externado de Colombia. For more information see Rodriguez (2019) and https://www.uexternado.edu.co/economia/colmodel-primer-modelo-de-microsimulacion-en-colombia/. The models for Bolivia and Venezuela have been developed as part of the LATINMOD project. LATINMOD is a regional tax-benefit microsimulation model for six Latin American countries (Argentina, Bolivia, Mexico, Paraguay, Uruguay and Venezuela). For more information, see Arancibia et al. (2019) and Oliva (2018). The model for Peru, PERUMOD, has been developed as part of the project "Simulating Tax Policy Reforms and Fiscal Gains in the Andean Region," which was funded by the Inter-American Development Bank.
} 


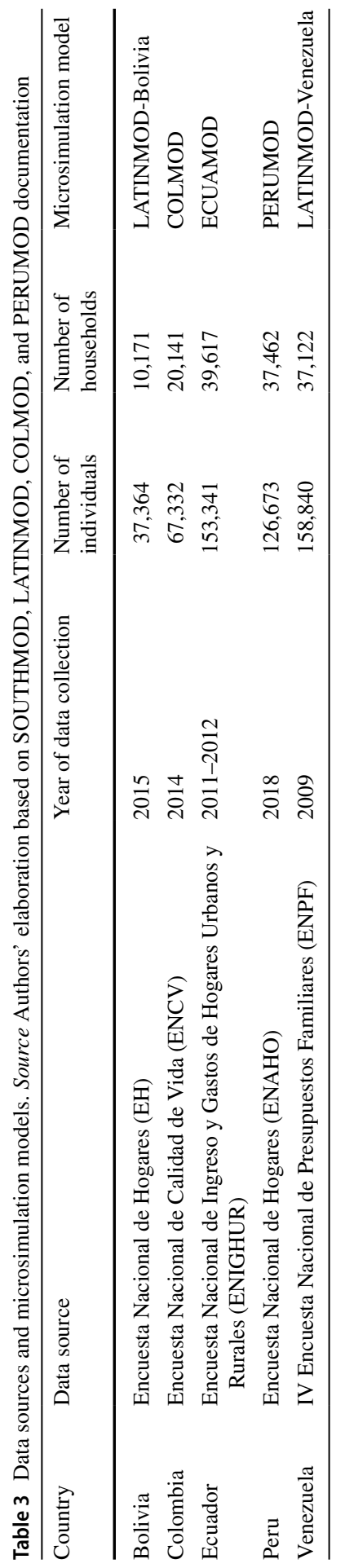


the microsimulation models and data used in the analysis. ${ }^{10}$ Appendix A provides a formal presentation of the tax-benefit microsimulation modeling approach.

The present analysis uses 2015 tax-benefit policies (as on June 30th) as the starting point in all five countries (i.e., social insurance contributions, personal income tax and benefits in force on 30 June 2015 are simulated for each household in the data). When the data year does not match the policy year, market incomes and nonsimulated tax-benefit variables are adjusted to 2015 levels using source-specific updating factors (Jara et al., 2019).

Scope of the simulations and assumptions Our analysis focuses on the concept of disposable income, defined as market income minus direct taxes and social insurance contributions plus cash benefits and pensions. ${ }^{11}$ In all five countries, the main policy components of disposable income have been simulated, including employee and self-employed social insurance contributions, personal income tax, and the main cash transfer programs of each country. ${ }^{12}$ Due to data limitations, some tax-benefit instruments cannot be simulated and are included directly from the data as part of disposable income. For example, contributory benefits such as public pensions and severance payments cannot be simulated due to the lack of data on contributions; disability benefits, due to insufficient information on the severity of the disability; and property taxes and motor vehicle taxes, due to the absence of information on value in both cases. With the exception of contributory pensions, all other non-simulated instruments represent a minor part of disposable income in the countries under study. Appendix A summarizes the main parameters of the tax-benefit instruments simulated in the models.

To account for the presence of informal employment in the analysis of the Andean countries, we use a harmonized approach to simulate social insurance contributions and personal income tax payments under partial compliance. More precisely, in all countries, employee and self-employed social insurance contributions are simulated only for workers reporting affiliations to social security in the survey. In Peru, only health insurance contributions are simulated for the self-employed, assuming that these individuals do not contribute to a pension fund (neither public nor private). In Venezuela, voluntary self-employed contributions are simulated for

\footnotetext{
${ }^{10}$ Data adjustments for the use in the microsimulation models are kept to a minimum. In particular, a minimum number of observations for domestic workers living in their employer's household have been dropped, as it is not possible to link them with information about their own households. An important shortcoming of the survey in Venezuela is that information about the household members' relationship to the head of the household is not released. Therefore, we have imputed information on mother and father identifiers for children that are less than 18 years old based on information about age, gender, and education level of adult household members.

11 Market income is defined as the sum of employment and self-employment income, bonuses, in-kind income, own consumption from self-employment activities, capital and property income, inter-household payments, private transfers, minus alimony payments. Imputed rent is not included as part of market income.

12 The following cash transfers are simulated in our models: Bono Juancito Pinto, Bono Juana Azurduy and Renta Dignidad in Bolivia; Familias en acción and Colombia Mayor in Colombia; Bono de Desarrollo Humano and Bono Joaquín Gallegos Lara in Ecuador; Juntos in Peru; Misiones educativas: Robinson (I y II), Ribas y Sucre and Gran Misión en Amor Mayor Venezuela in Venezuela.
} 
those individuals reporting affiliations to social security, but it is assumed that they pay the minimum (based on the minimum wage) independently from their income levels. ${ }^{13}$ For the simulation of personal income tax, we follow a similar approach and assume that only workers affiliated to social security pay taxes. In countries such as Ecuador and Venezuela, where social insurance contributions are voluntary for the self-employed, our assumption could be considered stringent, as some of the self-employed workers not affiliated to social security could in fact be paying income tax. In Bolivia, this assumption is relaxed for the self-employed, where personal income tax is simulated also for those registered in the general or simplified tax regimes.

\subsection{Measuring financial disincentives to formal employment implied by the tax-benefit system}

To quantify the financial cost of formalization, we follow Jara and Rodriguez (2019) and perform counterfactual simulations consisting of moving informal workers in the data into formal employment and comparing their household disposable income before and after the transition. As previously mentioned, transitions to formal employment are simulated for all those in the dataset between the ages of 18 and 60 currently working and reporting non-affiliation to social security (i.e., informal workers), excluding full-time students or retirees and those with very low earnings (i.e., below US\$1.9 per day).

More formally, our approach to simulate transitions from informal to formal employment consists of the following steps. First, household disposable income is calculated for all informal workers in the dataset before any transition is simulated. Then, for each informal worker in the household, we impose affiliation to social security in the data and assume that their earnings remain the same under the new status of formal workers. ${ }^{14}$ Finally, our tax-benefit models simulate the amount of social insurance contributions and personal income tax the worker would be liable to pay according to the legislation in force in 2015 , as well as his or her corresponding household disposable income under formalization. We simulate transitions to formal employment for each informal worker in household member separately, assuming that the status of any other informal workers remains unchanged.

\footnotetext{
13 In Venezuela, the social security law establishes the voluntary contribution of self-employed workers with a tax rate of 13 percent of declared income. In this case, the declared income is self-defined by workers but cannot be less than the minimum wage. Although no public information is available, assuming all affiliated self-employed contribute on the basis of the minimum wage seems a realistic assumption given the low social insurance contributions revenue in Venezuela.

14 Note that this assumption follows the original approach proposed by Koettl and Weber (2012), where earnings in formality are implicitly assumed to remain the same upon entry to formal employment. Jara and Rodriguez (2019) propose a different approach, whereby the earnings informal workers would face upon entry to formality are estimated based on the distribution of earnings of formal workers in the data. Potential changes in earnings upon entry to formal employment could be considered for future extensions of our work.
} 
This simulation makes it possible to analyze budgetary and distributional effects of entries to formality and quantify the financial incentives to formalization implied by the tax-benefit system, which we measure with FTR (Koettl, 2013; Koettl \& Weber, 2012; Weber, 2015). We follow Koettl and Weber (2012) and define FTR as the proportion of earnings in informal employment that would be taxed away after entry to formality. More precisely, we define FTR of individual i as:

$$
\mathrm{FTR}_{\mathrm{i}}=\frac{\mathrm{y}_{\mathrm{h}, \mathrm{i}}-\mathrm{y}_{\mathrm{h}, \mathrm{i}}^{\prime}}{\mathrm{x}_{w_{i}}}
$$

where $\mathrm{x}_{w_{i}}$ represents worker $i$ 's earnings in informal employment, $y_{h, i}$ represents household disposable income for worker $i$ in informal employment, and $y_{h, i}^{\prime}$ represents the counterfactual household disposable income for worker $i$ when they are moved to formal employment.

Different from previous studies that use hypothetical data to measure the burden of formalization implied by the tax-benefit system in European countries (Koettl, 2013; Koettl \& Weber, 2012; Weber, 2015), our models make it possible to calculate these indicators using household survey data from LAC countries (Jara \& Rodriguez, 2019). As such, we are able characterize the distribution of FTRs across populations and sub-populations, as well as select different categories of individuals for specific transitions into formal employment.

Caveats Our approach assumes that earnings of informal workers remain the same upon entry to formal employment for the calculation of FTRs. This assumption is made to obtain an FTR indicator which reflects the financial disincentives to enter formal employment implied by the design of the tax-benefit system, given the observed characteristics of the population. As suggested by Jara and Rodriguez (2019), assuming changes in earnings upon entry to formal employment would not only require imputing potential earnings for informal workers but also redefining the concept of FTR to measure the proportion of changes in earnings (rather than the proportion of earnings) that would be taxed away upon entry to formal employment. Under the latter approach, FTRs would capture the combined effect of changes in earnings and the design of tax-benefit policies, which would need to be disentangled. Moreover, FTRs incorporating changes in earnings might be sensitive to the method to impute earnings. For this reason, we opt for the original definition of FTRs, which captures the financial disincentives to formal employment implied by the tax-benefit system only.

However, it is important to note a number of caveats related to our definition of FTR. First, our analysis measures FTRs from the perspective of workers, as payroll taxes paid by employers are not factored into the financial disincentives of informal employees to enter formal work. Integrating payroll taxes as a cost for employees would increase their FTR. Even if they are not integrated into FTRs, it is important to bear in mind that higher costs for employers (i.e., additional payroll tax payments) might result in a reduction in wages for salaried workers, potentially increasing the formalization costs of informal employees. Second, our FTR indicator is a 'short-term' measure of financial disincentives implied by the tax-benefit system, in the sense that we assume that social insurance contributions are considered a cost 
in the short term. However, in the medium and long term, social insurance contributions give entitlement to the public health system and public pensions. These expected benefits are not taken into account in our FTR indicators. Third, our analysis assumes tax compliance upon entry to formal employment, in the sense that social insurance contributions and personal income tax is calculated on the basis of the totality of earnings reported by informal workers in the survey (i.e., no tax avoidance or tax evasion). Finally, our FTR indicators focus on the financial disincentives implied by the tax-benefit system. However, overall incentives to enter formal employment might be influenced by a large number of factors including, for instance, gender role attitudes and labor market constraints. Note that some of the caveats become more relevant in the second part of the empirical analysis, where we assess the budgetary and distribution effects of potential entries to formal employment (Sect. 4.2). We come back to these points when we discuss the results.

\section{Empirical results}

This section presents the results of our evaluation in two steps. First, it provides a comprehensive comparative analysis of the distribution and composition of FTR, as well as the variation of financial disincentives to formal employment across population subgroups in each of the five countries under analysis. Second, we simulate a number of counterfactual distributions where a fraction of informal workers would enter formal employment and assess the implications of such entries on personal income tax and social insurance contributions revenue, the number of taxpayers, and social insurance contribution payers, and income inequality.

\subsection{Financial disincentives to formal employment}

In this section, we use household representative data to calculate financial incentives to formal employment, allowing us to characterize the distribution of FTR at the population level of informal workers in each of the five countries and compare indicators across different subgroups. We focus on the contribution of different taxbenefit components to FTR. Based on this analysis and the heterogeneity in the data, we assess whether particular population subgroups face higher disincentives to enter formal employment. In particular, we distinguish between salaried employees and self-employed informal workers who have presented contrasting patterns (Jara \& Rodriguez, 2019). We also distinguish informal employees in firms of different sizes (i.e., micro, small, medium, and large). As they might face the lowest financial disincentives to formality in large firms, informal employees in those firms are also more likely to make the transition to formality. To broaden the analysis, we study the distribution of FTR across economic activities. 
Fig. 2 Distribution of FTR in 2015. Source Authors' calculations based on microsimulation models. Note Countries are ordered by mean FTR

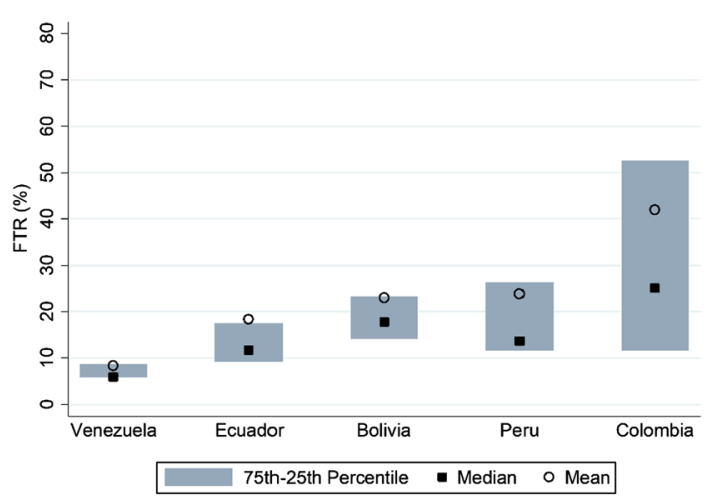

\subsubsection{Distribution of FTRs}

Figure 2 presents mean and median FTRs, as well as the inter-quartile range between the 25th and 75th percentile of FTR. The results show a large variation in financial incentives to enter formal employment across countries. The highest average FTR is in Colombia, where 42 percent of earnings in informality would be taxed away upon entry to formal employment as a result of increased social insurance contributions and tax payments or reduced benefits, and the lowest ( 8.5 percent) is in Venezuela. In between are Ecuador with 18.3 percent, Bolivia with 23.1 percent, and Peru with 23.9 percent.

The results further show that countries with higher values of average FTR are also characterized by a more dispersed distribution, depicted by the inter-quartile range. Venezuela shows very little variation of FTRs, while in Colombia inter-quartiles range between 11.4 percent ( 25 th percentile) and 52.7 percent ( 75 th percentile). In all countries, although to a lesser extent in Venezuela, the distribution of FTR is skewed to the right, with means higher than the median.

The differences in the distribution of FTR across countries can be explained by differences in: (i) the composition of the informal population and (ii) the design of tax-benefit policies. The following section provides further insights into the role of tax-benefit policies and population characteristics by analyzing the contribution of different policy instruments on FTRs across populations at different income levels.

\subsubsection{Decomposition of FTRs}

The distribution of FTR is determined by the design of specific tax-benefit instruments. We would expect that social insurance contributions contribute the most to FTR, as entry to formal employment implies affiliation to social security. Minimum and maximum social insurance contribution payments, or the presence of different contribution rates for specific categories of workers, would affect the distribution of FTRs. Personal income tax would also influence financial disincentives to formal employment. The extent to which it would contribute to FTRs depends on parameters such as the level of the exempted threshold, the structure of the tax schedule, 

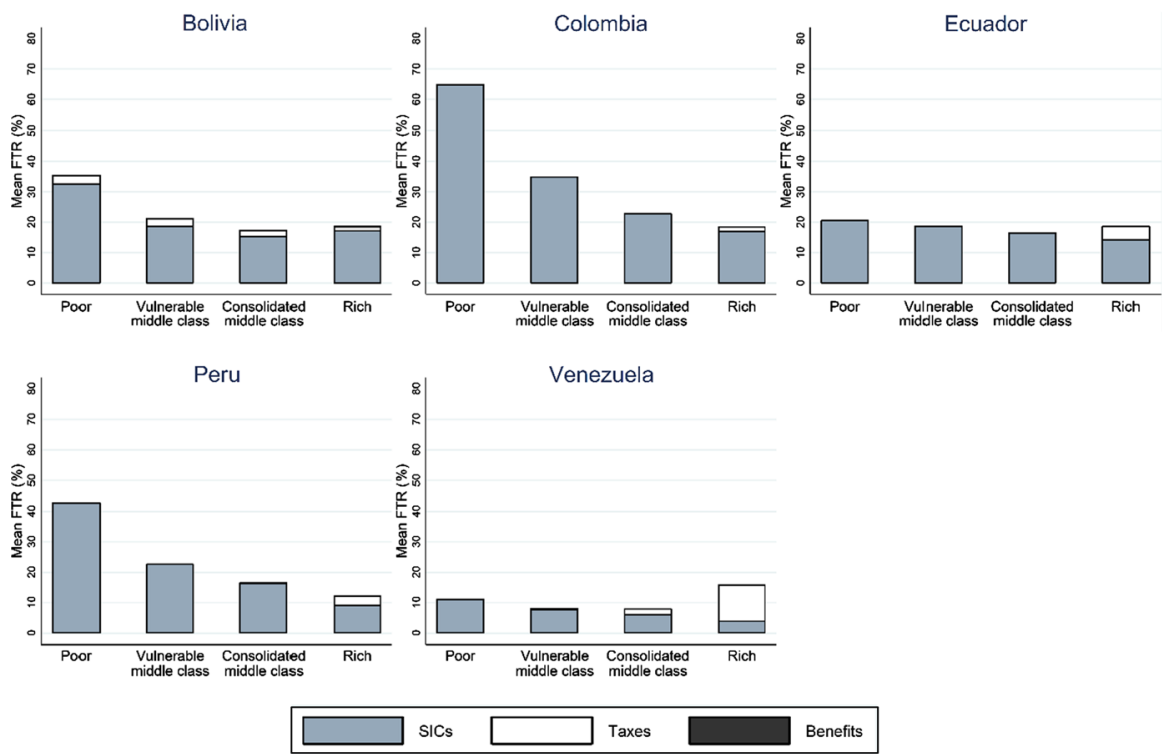

Fig. 3 Mean FTR decomposition in Andean countries by socio-economic Category, 2015. Source Authors' calculations based on microsimulation models. Note Socio-economic categories defined based on household disposable income per capita and the income thresholds specified by IDB (2020)

and the presence of tax deductions. Given the generosity of the design of the personal income tax in the countries under analysis, we do not expect it to have a large contribution to the FTR and to the decisions regarding potential formalization. Finally, cash transfers would also affect FTRs if entitlement to the benefit is linked to (non-)affiliation to social security.

In addition to the design of tax-benefit policies, the characteristics of the population in each country will also determine the distribution of FTRs. For instance, countries where informal workers' earnings are particularly low would present higher FTRs if social insurance contributions require minimum payments above the level of their earnings. An overrepresentation of self-employed workers in informality would also induce higher FTRs if the social insurance contribution rate is higher for this group compared to the rate for formal employees.

Figure 3 presents a decomposition of mean FTR. To account for the role of individual instruments at different points of the income distribution, the figure provides the decomposition across four socio-economic categories: poor, vulnerable middle class, consolidated middle class, and rich. The categories are defined based on household disposable income per capita and the income thresholds specified by the Inter-American Development Bank (IDB, 2020) included in the Appendix of this paper (Table 13).

Our results show that in all countries except Venezuela, mean FTR decreases with income and social insurance contributions contribute the most to FTR. Financial disincentives to formal employment are particularly high for poor informal workers in Colombia, with FTR of 65 percent. This reflects mainly lower average 
earnings in this population group compared to earnings for the same group in other Andean countries, ${ }^{15}$ as well as relatively high self-employed contribution rates of 28.5 or 30.5 percent. $^{16}$

In general, direct taxes play only a minor role in determining FTR. In Colombia, Ecuador, and Peru, direct taxes contribute to FTR of wealthy informal workers only. Direct taxes represent 1.4, 4.2, and 3.2 percentage points of average FTR for Colombia, Ecuador, and Peru, respectively. In Venezuela, they play a larger role than social insurance contributions for the rich, contributing with 11.8 percentage points to their average FTR (15.7 percent) and, to a lesser extent, for the consolidated middle class. In the case of Venezuela, the misalignment between the evolution of prices and wages and the parameters of the personal income tax (the Unidad Tributaria) make its structure similar to that in more developed countries in terms of progressivity, which explains the larger contribution of taxes to FTR. In fact, it is due to the role of direct taxes that FTRs are U-shaped in income, rather than presenting the decreasing pattern observed in other countries.

Bolivia is the only country where direct taxes contribute to FTR throughout the income distribution. In Bolivia, personal income tax is part of the Régimen Complementario del Impuesto al Valor Agregado (RC-IVA), which allows the value added tax (VAT) paid on purchases to be deducted from the income tax liability. Since the parameters of the standard and VAT deductions are the same across the income distribution, the income tax is not progressive. On the contrary, it slightly favors individuals with higher incomes whose VAT purchases are higher. Another reason is the tax on self-employed workers, where no exempted income threshold applies. The contribution of direct taxes remains, however, modest in all five countries, which is due to two main characteristics of design of personal income tax in LAC countries, in which the Andean region is not an exception. In all countries, except Bolivia, personal income tax is characterized by the presence of high non-taxable thresholds, meaning that in the event of entering formal employment, most informal workers would not fall into the tax brackets that would make them liable to pay income taxes. Moreover, deductions from personal expenditures can be made from taxable income, which reduce the volume of taxpayers. Finally, the contribution of cash transfers to FTRs is extremely limited (or null) because eligibility to social benefits in these countries is based on composite welfare indexes (i.e., proxy means-testing), which do not directly depend on affiliation to social security. ${ }^{17}$

\footnotetext{
15 The monthly gross labor income of informal workers in the poor segments in Colombia is estimated at COL 300,000, equivalent to US\$95. On the other hand, monthly labor income in Peru, Bolivia, and Ecuador amounts to US\$110, US\$150 and US\$212, respectively.

16 This information is based on legislation in force as of 2015. Minimum self-employed social insurance contribution rates equal 14 percent in Bolivia, 20.5 percent in Ecuador, 13 percent in Venezuela and fixed health insurance contribution payments depending on age in Peru.

17 In Ecuador, eligibility to social benefits (i.e., Bono de Desarrollo Humano) for the elderly and the disabled depends on non-affiliation to social security. However, these groups are not included in our sample of analysis.
} 


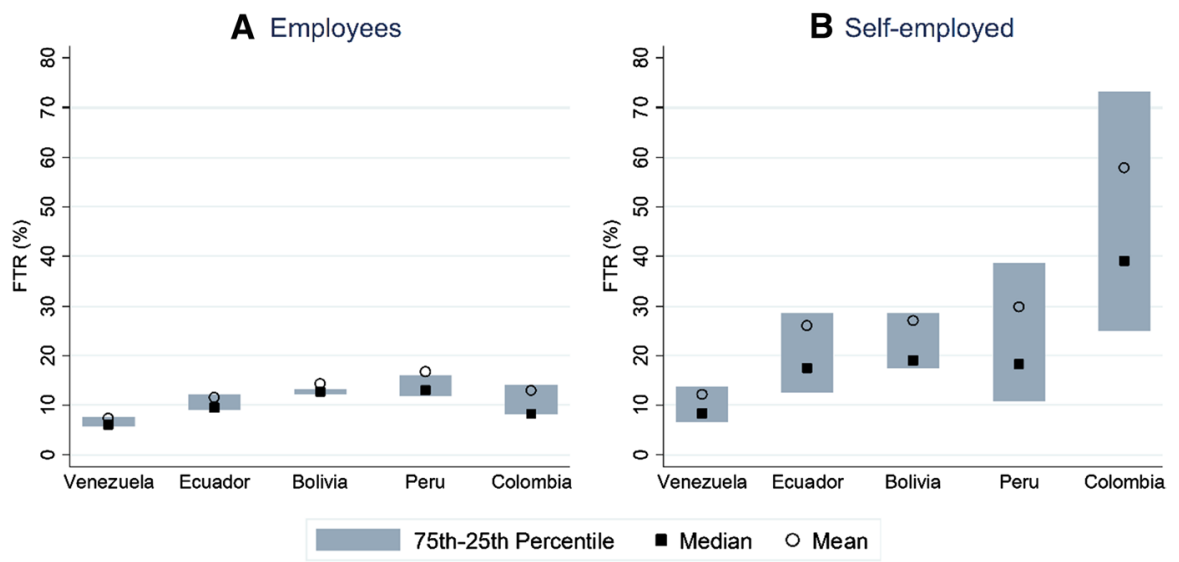

Fig. 4 Distribution of FTR by employment Status, 2015. Source Authors' calculations based on microsimulation models. Note Countries are ordered by mean FTR of the self-employed

\subsubsection{Heterogeneity across population subgroups}

The previous section pointed to the interaction between the design of tax-benefit policies and the characteristics of the population-namely income-in determining FTR. This section exploits the advantage of using representative household survey data to assess whether indicators of FTR vary across different population subgroups, such as by gender, age, skill level, employment status, region, and economic activity.

Figure 4 compares the distribution of FTR distinguishing between informal employees and informal self-employed workers. This comparison is interesting because the prevalence of self-employment among informal workers varies across countries (see Table 12 in the Appendix) and, at the same time, the rules of social insurance contributions are specific to each of these employment statuses. Our results show that the wide variation in the overall distribution of FTR across the five countries (see Fig. 2) is mainly driven by the distribution of FTR of the self-employed. In fact, mean FTRs for employees vary minimally across countries, ranging between 7.3 percent in Venezuela and 16.8 percent in Peru. On the contrary, important differences are observed in terms of financial disincentives to formal employment for self-employed workers, who face on average higher FTRs than employees in all countries. FTRs are particularly high for self-employed workers in Colombia, for whom 57.9 percent of their earnings in informality would be taxed away upon entry to formal employment. In Ecuador, Bolivia, and Peru, selfemployed workers face similar FTRs, ranging between 26 and 30 percent on average. Venezuela is the only country where the FTR of the self-employed remains low (12 percent). Looking at the distribution of FTR for employees versus self-employed workers, there is a wide variation in terms of inter-quartile ranges, driven mainly by the dispersion of FTR observed for the self-employed.

The large financial disincentives to formal employment observed for selfemployed workers in Colombia can be explained by three factors. First, the 


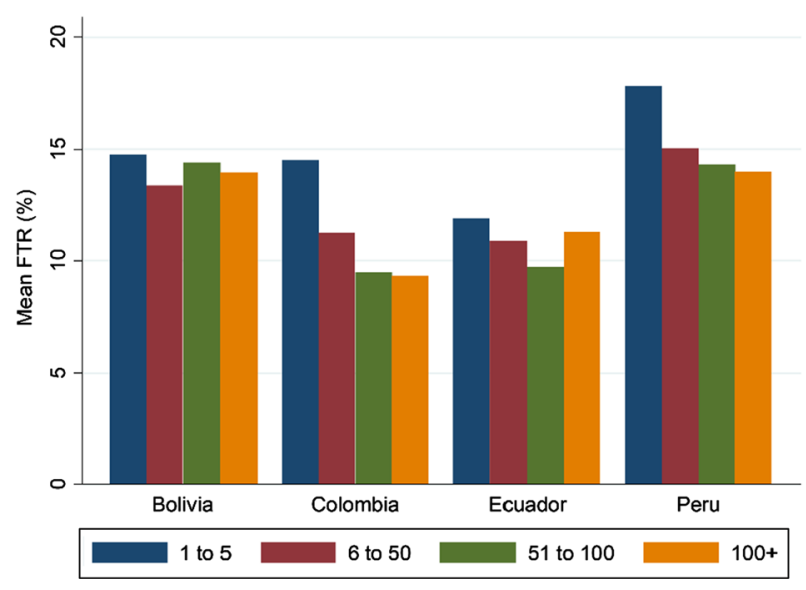

Fig. 5 Mean FTR of employees by number of workers in the firm, 2015. Source Authors' calculations based on microsimulation models. Note Data for Venezuela are not available

proportion of informal self-employed workers is larger than in other countries. Self-employed workers account for 64.6 percent of our sample of informal workers in Colombia (see Table 12 in the appendix). Only Bolivia shows a higher prevalence of self-employed informal workers (69.6), whereas the levels are much lower in Ecuador (40.2) and Venezuela (25.9). Second, labor income is low in Colombia compared to the other Andean countries. According to our estimates, monthly labor income is US\$209 in Colombia compared to US\$360 in Peru, US\$392 in Bolivia, and US\$478 in Ecuador. Finally, as explained earlier, Colombia presents higher selfemployed contribution rates than the other countries under analysis. In any case, the pattern of high FTR among the self-employed is expected since these workers tend to earn less than their salaried counterparts and their earnings are more volatile.

To explore more deeply the differences in financial disincentives to formal employment among employees, Fig. 5 presents mean FTRs by the size of the firm in which employees work in all countries except Venezuela (due to lack of data). In Bolivia, Colombia, Ecuador, and Peru, employees working in firms with 1-5 workers present higher FTR than employees in larger firms. The pattern is consistent with the discussion about the relationship between firm size and productivity, which might regroup low-skilled and low-paid workers. Colombia and Peru show a clear decreasing pattern of FTR by firm size. The gap in mean FTR of employees in small firms (1-5 workers) compared to big firms (more than 100 workers) equals 5 percentage points in Colombia and 3.7 percentage points in Peru. The relatively minor differences in FTR observed are explained by the fact that the design of employee social insurance contributions does not vary across firm size. The differences are mainly due to the varied composition of the workforce across firms.

In addition to differences in FTRs between salaried employees and the selfemployed workers - which are related to the composition of the labor market, wage structure, and design of social insurance contributions-there could be other patterns for population subgroups based on varying characteristics of gender, age, skill 
Table 4 Mean FTRs by population subgroups, 2015. Source Authors' calculations based on microsimulation models

\begin{tabular}{|c|c|c|c|c|c|}
\hline & Bolivia & Colombia & Ecuador & Peru & Venezuela \\
\hline All & 23.1 & 42.0 & 18.3 & 23.9 & 8.5 \\
\hline Male & 21.4 & 37.5 & 13.9 & 20.2 & 8.0 \\
\hline Female & 26.2 & 49.7 & 25.8 & 29.0 & 9.3 \\
\hline Age $(<30)$ & 19.5 & 39.0 & 16.0 & 20.8 & 7.6 \\
\hline Age $(30-50)$ & 23.1 & 41.3 & 18.7 & 23.4 & 8.7 \\
\hline Age $(50+)$ & 28.6 & 49.1 & 21.5 & 29.2 & 9.7 \\
\hline Low-skilled & 27.5 & 52.6 & 17.8 & 34.3 & 8.6 \\
\hline Medium-skilled & 20.4 & 37.6 & 19.4 & 22.2 & 8.1 \\
\hline High-skilled & 19.4 & 26.5 & 16.5 & 12.3 & 10.0 \\
\hline Employee & 14.3 & 12.9 & 11.5 & 16.8 & 7.2 \\
\hline Self-employed & 27.1 & 58.0 & 26.1 & 29.9 & 12.1 \\
\hline Rural & 30.4 & 60.4 & 14.0 & 34.4 & 8.8 \\
\hline Urban & 19.9 & 36.0 & 20.3 & 21.4 & 8.5 \\
\hline Agriculture and fishing & 34.4 & 55.6 & 9.6 & 32.6 & 8.5 \\
\hline Mining, manufacturing, and utilities & 21.0 & 39.5 & 21.4 & 22.6 & 8.9 \\
\hline Construction & 15.5 & 29.8 & 12.4 & 15.0 & 8.8 \\
\hline $\begin{array}{l}\text { Retail, wholesale, hotels, and restau- } \\
\text { rants }\end{array}$ & 22.9 & 41.4 & 25.0 & 25.3 & 8.1 \\
\hline Transport and communication & 18.4 & 39.2 & 17.3 & 16.1 & 9.3 \\
\hline $\begin{array}{l}\text { Financial intermediation, real estate, } \\
\text { and business activities }\end{array}$ & 12.7 & 39.2 & 19.8 & 18.8 & 8.5 \\
\hline Other industry sectors & 19.6 & 35.8 & 22.0 & 20.0 & 7.2 \\
\hline Income quintile 1 & 43.6 & 84.5 & 20.5 & 45.7 & 10.1 \\
\hline Income quintile 2 & 25.0 & 47.3 & 19.0 & 25.4 & 8.2 \\
\hline Income quintile 3 & 21.2 & 37.3 & 18.9 & 20.6 & 7.7 \\
\hline Income quintile 4 & 18.9 & 29.7 & 17.7 & 17.5 & 7.3 \\
\hline Income quintile 5 & 16.9 & 20.3 & 15.5 & 14.5 & 9.4 \\
\hline Number of observations & 7165 & 14,498 & 28,830 & 28,274 & 30,273 \\
\hline
\end{tabular}

Income quintiles are based on per capita household disposable income

level, location, economic activity, and income. Table 4 presents mean FTR across different population subgroups.

A gender divide in financial disincentives to enter formal employment is observed in all five countries. Female informal workers present higher FTRs than their male counterparts. The gap in FTRs is the largest in Colombia, representing a 12.2 percentage point difference (49.7 percent versus 37.5 percent), followed closely by Ecuador, where female informal workers face an FTR 11.9 points higher than male informal workers (25.8 percent versus 13.9 percent). The differences in FTR between male and female workers are driven by the characteristics of these groups. On average, there is a higher prevalence of low-skilled, self-employed female 
workers, which most likely leads to lower incomes. Table 4 confirms that these characteristics are associated with higher levels of FTR.

The results also show pronounced differences between workers in rural and urban areas. In all countries, except Ecuador, informal workers in rural areas face higher FTRs than those in urban areas. The gap is the largest in Colombia, where rural informal workers face an FTR almost twice as large as their urban counterparts (35.9 percent versus 60.4 percent). The gap is larger than 10 percentage points in Peru (34.4 percent versus 21.4 percent) and Bolivia (30.4 percent versus 19.9 percent). A contrasting pattern is observed in Ecuador, where rural informal workers face an FTR 6.3 points lower than their urban counterparts (14 percent versus 20.3 percent). The rural-urban pattern observed in Ecuador relates to the presence of Seguro Campesino in Ecuador, a social insurance regime for self-employed rural workers with lower contribution rates than the general regime. Under Seguro Campesino, the amount of social insurance contributions paid by members of this regime is equal to 2.5 percent of 22.5 percent of the minimum wage, compared to a 20.5 percent contribution rate on gross employment income for other categories of selfemployed workers.

Differences in financial disincentives to formal employment are also observed across economic activities. In Bolivia, Colombia, and Peru, mean FTRs are the largest in the agriculture and fishing sector. The results are consistent with the patterns observed between informal workers in rural and urban areas, as agriculture and fishing activities are mainly located in rural regions. Consistent with this pattern, mean FTRs for agriculture and fishing are the lowest in Ecuador, again mainly due to the presence of Seguro Campesino, which covers rural workers in these sectors of activity. Both the mining, manufacturing, and utilities sector and the retail, wholesale, hotels, and restaurants sector also present higher FTR than other industries, especially in Colombia. The lowest mean FTRs are observed in the construction sector in Colombia, and Peru. In Ecuador, the construction sector, along with the agriculture and fishing sector, presents low mean FTRs. In Bolivia, the construction sector follows that of financial intermediation, real estate, and business activities, in terms of the lowest mean FTRs. Finally, in Venezuela, the results do not show a clear pattern, with similar mean FTRs across sectors.

To analyze the association between individual characteristics and financial disincentives to formal employment, we regress mean FTRs on the set of characteristics discussed above. Table 5 shows the results.

To account for the role of earnings in determining the level of FTRs, in addition to the logarithm of earnings, we include a dummy variable identifying informal workers with very low earnings, i.e., below half of the minimum wage in each country. Our results show that having earnings below half of the minimum wage is positively correlated with higher FTRs, whereas the logarithm of earnings has a negative and significant effect capturing the fact that FTRs decrease with the level of earnings. The only exception to the latter is Venezuela, where the logarithm of earnings has a positive and significant effect, which is in line with the U-shaped form observed in Fig. 3 due to the contribution of personal income tax to FTRs at the top of the distribution in Venezuela. Our low-earnings dummy and the logarithm 
Table 5 OLS regression estimates of FTRs. Source Authors' calculations based on microsimulation models

\begin{tabular}{|c|c|c|c|c|c|}
\hline & Bolivia & Colombia & Ecuador & Peru & Venezuela \\
\hline Female & $\begin{array}{l}-0.577 * * * \\
(0.237)\end{array}$ & $\begin{array}{l}-0.135 \\
(0.629)\end{array}$ & $\begin{array}{l}-1.509^{* * * *} \\
(0.249)\end{array}$ & $\begin{array}{l}-0.936^{* * * *} \\
(0.191)\end{array}$ & $\begin{array}{l}0.625 * * * \\
(0.0485)\end{array}$ \\
\hline Age & $\begin{array}{l}0.189 * * * \\
(0.0572)\end{array}$ & $\begin{array}{l}0.190 \\
(0.151)\end{array}$ & $\begin{array}{l}0.668 * * * \\
(0.0605)\end{array}$ & $\begin{array}{l}-0.0963^{* *} \\
(0.0459)\end{array}$ & $\begin{array}{l}0.0222 \\
(0.0137)\end{array}$ \\
\hline $\mathrm{Age}^{2}$ & $\begin{array}{l}-0.00201 * * * \\
(0.000729)\end{array}$ & $\begin{array}{l}-0.00194 \\
(0.00192)\end{array}$ & $\begin{array}{l}-0.00805^{* * * *} \\
(0.000778)\end{array}$ & $\begin{array}{l}0.00232 * * * \\
(0.000582)\end{array}$ & $\begin{array}{l}-1.00 \mathrm{e}-05 \\
(0.000176)\end{array}$ \\
\hline Middle-skilled & $\begin{array}{l}-0.106 \\
(0.217)\end{array}$ & $\begin{array}{l}1.311 * * * \\
(0.595)\end{array}$ & $\begin{array}{l}0.0369 \\
(0.228)\end{array}$ & $\begin{array}{l}-0.0337 \\
(0.222)\end{array}$ & $\begin{array}{l}0.117 * * \\
(0.0470)\end{array}$ \\
\hline High-skilled & $\begin{array}{l}-0.00784 \\
(0.346)\end{array}$ & $\begin{array}{l}11.54 * * * \\
(1.075)\end{array}$ & $\begin{array}{l}-1.942 * * * \\
(0.350)\end{array}$ & $\begin{array}{l}4.192 * * * \\
(1.413)\end{array}$ & $\begin{array}{l}1.822 * * * \\
(0.0821)\end{array}$ \\
\hline Rural & $\begin{array}{l}0.442 * \\
(0.293)\end{array}$ & $\begin{array}{l}3.289 * * * \\
(0.627)\end{array}$ & $\begin{array}{l}-2.590 * * * \\
(0.262)\end{array}$ & $\begin{array}{l}0.138 \\
(0.196)\end{array}$ & $\begin{array}{l}0.255 * * * \\
(0.0881)\end{array}$ \\
\hline Self-employed & $\begin{array}{l}7.605 * * * \\
(0.224)\end{array}$ & $\begin{array}{l}41.66^{* * *} \\
(0.559)\end{array}$ & $\begin{array}{l}10.40 * * * \\
(0.233)\end{array}$ & $\begin{array}{l}6.210 * * * \\
(0.171)\end{array}$ & $\begin{array}{l}3.407 * * * \\
(0.0525)\end{array}$ \\
\hline $\begin{array}{l}\text { Mining, manufacturing, } \\
\text { and utilities }\end{array}$ & $\begin{array}{l}-1.171^{* * * *} \\
(0.399)\end{array}$ & $\begin{array}{l}3.768 * * * \\
(1.024)\end{array}$ & $\begin{array}{l}13.17 * * * \\
(0.386)\end{array}$ & $\begin{array}{l}2.862 * * * \\
(0.327)\end{array}$ & $\begin{array}{l}0.223^{* *} \\
(0.103)\end{array}$ \\
\hline Construction & $\begin{array}{l}0.0141 \\
(0.404)\end{array}$ & $\begin{array}{l}-0.905 \\
(1.087)\end{array}$ & $\begin{array}{l}11.04 * * * \\
(0.383)\end{array}$ & $\begin{array}{l}3.376^{* * *} \\
(0.335)\end{array}$ & $\begin{array}{l}-0.0179 \\
(0.0850)\end{array}$ \\
\hline $\begin{array}{l}\text { Retail, wholesale, hotels, } \\
\text { and restaurants }\end{array}$ & $\begin{array}{l}-0.156 \\
(0.379)\end{array}$ & $\begin{array}{l}0.550 \\
(0.823)\end{array}$ & $\begin{array}{l}13.48 * * * \\
(0.343)\end{array}$ & $\begin{array}{l}1.164 * * * \\
(0.249)\end{array}$ & $\begin{array}{l}-0.201^{*} \\
(0.0993)\end{array}$ \\
\hline Transport and communication & $\begin{array}{l}-0.542 \\
(0.427)\end{array}$ & $\begin{array}{l}-1.254 \\
(1.061)\end{array}$ & $\begin{array}{l}11.99 * * * \\
(0.430)\end{array}$ & $\begin{array}{l}-1.429 * * * \\
(0.313)\end{array}$ & $\begin{array}{l}0.346^{* * * *} \\
(0.0995)\end{array}$ \\
\hline $\begin{array}{l}\text { Financial intermediation, } \\
\text { real estate, and business activi- } \\
\text { ties }\end{array}$ & $\begin{array}{l}0.320 \\
(1.995)\end{array}$ & $\begin{array}{l}4.593 * * * \\
(1.301)\end{array}$ & $\begin{array}{l}13.72 * * * \\
(0.622)\end{array}$ & $\begin{array}{l}1.433 * * * \\
(0.489)\end{array}$ & $\begin{array}{l}0.0920 \\
(0.141)\end{array}$ \\
\hline Other industry sectors & $\begin{array}{l}-1.386^{* * * *} \\
(0.437)\end{array}$ & $\begin{array}{l}-0.429 \\
(1.014)\end{array}$ & $\begin{array}{l}13.19 * * * \\
(0.396)\end{array}$ & $\begin{array}{l}2.033 * * * \\
(0.302)\end{array}$ & $\begin{array}{l}-0.906 * * * \\
(0.0939)\end{array}$ \\
\hline $\begin{array}{l}\text { Low earner (below } 0.5 * \text { mini- } \\
\text { mum wage) }\end{array}$ & $\begin{array}{l}21.47 * * * \\
(0.348)\end{array}$ & $\begin{array}{l}6.118 * * * \\
(0.684)\end{array}$ & $\begin{array}{l}11.49 * * * \\
(0.361)\end{array}$ & $\begin{array}{l}24.02 * * * \\
(0.249)\end{array}$ & $\begin{array}{l}22.99 * * * \\
(0.142)\end{array}$ \\
\hline Log earnings & $\begin{array}{l}-7.716^{* * * *} \\
(0.153)\end{array}$ & $\begin{array}{l}-43.32 * * * \\
(0.449)\end{array}$ & $\begin{array}{l}-10.53 * * * \\
(0.193)\end{array}$ & $\begin{array}{l}-14.50 * * * \\
(0.128)\end{array}$ & $\begin{array}{l}0.996 * * * \\
(0.0389)\end{array}$ \\
\hline Constant & $\begin{array}{l}69.63 * * * \\
(1.154)\end{array}$ & $\begin{array}{l}570.5 * * * \\
(3.294)\end{array}$ & $\begin{array}{l}50.29 * * * \\
(1.239)\end{array}$ & $\begin{array}{l}112.0 * * * \\
(0.952)\end{array}$ & $\begin{array}{l}-3.938 * * * \\
(0.266)\end{array}$ \\
\hline Number of observations & 7165 & 14,498 & 28,830 & 28,274 & 30,273 \\
\hline$R^{2}$ & 0.772 & 0.761 & 0.440 & 0.783 & 0.553 \\
\hline
\end{tabular}

Standard errors in parenthesis; significance level: ${ }^{*} p<0.1, * * p<0.05, * * * p<0.01$

of earnings account for a large share of the variation in FTRs, from 68 percent of the variation in Ecuador to 92 percent of the variation in Bolivia.

In line with the descriptive assessment of FTRs across population subgroups, being self-employed is significantly associated with higher FTRs. The effect of 
being a rural worker is negative and significant in Ecuador, in line with the discussion about the role of Seguro Campesino. On the contrary, after controlling for other variables, the coefficient for female informal workers has a positive and significant effect only in Venezuela, meaning that higher mean FTR for females (Table 4) are explained by differences in earnings and other covariates included in the regression.

\subsection{Assessing the distributional and budgetary implications of formalization}

Informality is usually discussed in the literature as a barrier to increase fiscal capacity and boost long-term growth in developing countries (see OECD et al., 2021). Yet, little is known about the budgetary and, in particular, distributional implications of potential entries to formal employment. In this section, we simulate a number of counterfactual distributions where a fraction of informal workers would enter formal employment. We then assess the implications of such entries on tax revenue, the number of taxpayers, and income inequality. The analysis is static, in the sense that it does not consider behavioral responses due to potential entries to formal employment, neither does it consider the fact that the structure of wages might change as a result of entries to formality. In this sense, the results should be interpreted as first round effects with the aim of providing insight into the effects of potential transitions from informal to formal employment, with a focus on the characteristics of the labor force and design of tax-benefits systems.

In contrast with the previous section, here we assume that upon entry to formal employment informal employees would earn at least the minimum wage (i.e., the firms where they are employed would comply with the minimum wage legislation). Earnings of self-employed informal workers are kept fixed upon entry to informal employment as they are not automatically entitled to receive the minimum wage (i.e., they are not employees working for firms) and their earnings usually fluctuate depending on their economic activity. Note, for instance, that an important share of the actual self-employed formal workers in the data has earnings below the minimum wage, ranging between 16 percent in Colombia and 47 percent in Ecuador (Figure 11 in Appendix B).

It is important to acknowledge that the probability of entering formal employment is not uniformly distributed across all informal workers. As suggested in the previous section, some population subgroups face overly high FTRs and therefore, could be less likely to move to formal employment. From the demand-side, low-skilled workers could face difficulties finding work in the formal sector. For this reason, our approach works in two steps. First, we rank workers in informal employment by their probability of being formal. Then, we simulate counterfactual distributions where a fraction of informal workers would enter formal employment based on their probability of being formal.

The counterfactual simulations work as follows. First, the 10 percent of informal workers with the highest probability of being formal are moved into formal employment by means of tax-benefit microsimulation. Then, cumulatively, the next 10 percent of informal workers with the highest probability of being formal are moved to formality, until we assess the effect of moving all informal workers to formal 
Table 6 Probit estimates of the probability of being in formal employment. Source Authors' calculations based on microsimulation models

\begin{tabular}{|c|c|c|c|c|c|}
\hline & Bolivia & Colombia & Ecuador & Peru & Venezuela \\
\hline Male & $\begin{array}{l}0.160 * * * \\
(0.0404)\end{array}$ & $\begin{array}{l}0.0912 * * * \\
(0.0294)\end{array}$ & $\begin{array}{l}-0.155 * * * \\
(0.0170)\end{array}$ & $\begin{array}{l}-0.177 * * * \\
(0.0186)\end{array}$ & $\begin{array}{l}-0.0932 * * * \\
(0.0142)\end{array}$ \\
\hline Age & $\begin{array}{l}0.0389 * * * \\
(0.0111)\end{array}$ & $\begin{array}{l}0.0428 * * * \\
(0.00811)\end{array}$ & $\begin{array}{l}0.0192 * * * \\
(0.00467)\end{array}$ & $\begin{array}{l}0.0658 * * * \\
(0.00538)\end{array}$ & $\begin{array}{l}0.00821^{*} \\
(0.00458)\end{array}$ \\
\hline $\mathrm{Age}^{2}$ & $\begin{array}{l}-0.000365^{* *} \\
(0.000143)\end{array}$ & $\begin{array}{l}-0.000456^{* * *} \\
(0.000104)\end{array}$ & $\begin{array}{l}-0.000104 * \\
(6.02 \mathrm{e}-05)\end{array}$ & $\begin{array}{l}-0.000631 * * * \\
(6.79 \mathrm{e}-05)\end{array}$ & $\begin{array}{l}2.73 \mathrm{e}-05 \\
(5.89 \mathrm{e}-05)\end{array}$ \\
\hline Middle-skilled & $\begin{array}{l}0.378 * * * \\
(0.0428)\end{array}$ & $\begin{array}{l}0.397 * * * \\
(0.0335)\end{array}$ & $\begin{array}{l}0.193 * * * \\
(0.0169)\end{array}$ & $\begin{array}{l}0.501^{* * * *} \\
(0.0315)\end{array}$ & $\begin{array}{l}0.216^{* * * *} \\
(0.0158)\end{array}$ \\
\hline High-skilled & $\begin{array}{l}0.825 * * * \\
(0.0586)\end{array}$ & $\begin{array}{l}0.666 * * * \\
(0.0453)\end{array}$ & $\begin{array}{l}0.379 * * * \\
(0.0249)\end{array}$ & $\begin{array}{l}0.968 * * * \\
(0.0781)\end{array}$ & $\begin{array}{l}0.191 * * * \\
(0.0247)\end{array}$ \\
\hline Married & $\begin{array}{l}0.205 * * * \\
(0.0357)\end{array}$ & $\begin{array}{l}0.0666 * * \\
(0.0289)\end{array}$ & $\begin{array}{l}0.242 * * * \\
(0.0148)\end{array}$ & $\begin{array}{l}0.388 * * * \\
(0.0185)\end{array}$ & $\begin{array}{l}0.135 * * * \\
(0.0146)\end{array}$ \\
\hline Number of children & $\begin{array}{l}-0.0588^{* * * *} \\
(0.0121)\end{array}$ & $\begin{array}{l}-0.0385^{* * * *} \\
(0.0103)\end{array}$ & $\begin{array}{l}-0.0417 * * * \\
(0.00483)\end{array}$ & $\begin{array}{l}-0.0389 * * * \\
(0.00695)\end{array}$ & $\begin{array}{l}-0.0246^{* * * *} \\
(0.00467)\end{array}$ \\
\hline Rural & $\begin{array}{l}0.0112 \\
(0.0523)\end{array}$ & $\begin{array}{l}0.0766 * * \\
(0.0319)\end{array}$ & $\begin{array}{l}0.266 * * * \\
(0.0183)\end{array}$ & $\begin{array}{l}-0.362 * * * \\
(0.0234)\end{array}$ & $\begin{array}{l}-0.202 * * * \\
(0.0309)\end{array}$ \\
\hline Self-employed & $\begin{array}{l}-0.982 * * * \\
(0.0389)\end{array}$ & $\begin{array}{l}-1.307 * * * \\
(0.0275)\end{array}$ & $\begin{array}{l}-1.143 * * * \\
(0.0187)\end{array}$ & $\begin{array}{l}-0.695 * * * \\
(0.0181)\end{array}$ & $\begin{array}{l}-0.770 * * * \\
(0.0209)\end{array}$ \\
\hline Log(earnings) & $\begin{array}{l}0.410^{* * *} \\
(0.0249)\end{array}$ & $\begin{array}{l}0.787 * * * \\
(0.0208)\end{array}$ & $\begin{array}{l}0.531 * * * \\
(0.0106)\end{array}$ & $\begin{array}{l}0.416^{* * * *} \\
(0.0112)\end{array}$ & $\begin{array}{l}0.228 * * * \\
(0.0111)\end{array}$ \\
\hline Constant & $\begin{array}{l}-4.546 * * * \\
(0.262)\end{array}$ & $\begin{array}{l}0.335 * * * \\
(0.0480)\end{array}$ & $\begin{array}{l}-0.0349^{*} \\
(0.0197)\end{array}$ & $\begin{array}{l}-0.250 * * * \\
(0.0458)\end{array}$ & $\begin{array}{l}0.102 * * * \\
(0.0247)\end{array}$ \\
\hline Industry dummies & Yes & Yes & Yes & Yes & Yes \\
\hline Occupation dummies & Yes & Yes & Yes & Yes & Yes \\
\hline Region dummies & Yes & Yes & Yes & Yes & Yes \\
\hline Number of observations & 11,368 & 23,449 & 51,639 & 46,840 & 47,829 \\
\hline Pseudo $R^{2}$ & 0.421 & 0.466 & 0.330 & 0.365 & 0.153 \\
\hline
\end{tabular}

Standard errors in parenthesis; significance level: $* p<0.1, * * p<0.05, * * * p<0.01$

employment. For each of these counterfactual distributions, we assess the additional tax revenue and number of taxpayers due to transitions to formality, as well as the effect of such transitions on income inequality.

\subsubsection{Probability of being in formal employment}

We use a probit model to estimate the probability of being in formal employment. The dependent variable takes the value one if the person is in formal employment (is affiliated to social security) and zero otherwise. Variables traditionally used in the literature discussing the determinants of formality are used as regressors and include the following: gender (male), age and age squared, education (skill levels), marital 
Table 7 Tax Revenue under the baseline and counterfactual scenarios (in percent). Source Authors' elaboration based on own simulations and official sources

\begin{tabular}{|c|c|c|c|c|c|}
\hline & Bolivia & Colombia & Ecuador & Peru & Venezuela \\
\hline \multicolumn{6}{|l|}{ Baseline tax revenue $(\% G D P)^{a}$} \\
\hline Personal income tax & 0.22 & 0.80 & 1.03 & 1.45 & 0.80 \\
\hline Social insurance contributions & 4.32 & 9.28 & 2.51 & 2.07 & 0.48 \\
\hline \multicolumn{6}{|l|}{ Additional tax revenue $(\% G D P)^{b}$} \\
\hline Personal income tax & 0.55 & 0.02 & 0.16 & 0.10 & 1.30 \\
\hline Social insurance contributions & 4.69 & 2.12 & 1.98 & 2.01 & 0.85 \\
\hline
\end{tabular}

${ }^{a}$ Baseline results for Venezuela are based on our own simulations due to lack of official information on tax revenue. 'Authors' calculations based on microsimulation models. The counterfactual scenario corresponds to one with full formalization of informal workers

status (married), number of children, rural area, employment status (self-employed), the logarithm of earnings and a dummy identifying individuals below the minimum wage. Table 6 presents the results of the estimation.

Our results show that earnings are a strong determinant of the probability of being formal. In all countries, the probability of being formal increases with the logarithm of earnings. Controlling for other variables, being male increases the probability of being formal in Bolivia and Colombia, but it decreases it in Ecuador, Peru, and Venezuela. The probability of being formal increases with age at a decreasing rate, except in Venezuela, where the coefficient of age squared is positive and not significant. The probability of being formal increases with education level, even after controlling for earnings.

In all five countries, being self-employed is associated with a lower probability of being formal. In terms of family characteristics, being married increases the probability of being formal, whereas the probability decreases with the number of children, probably capturing the fact that low income families where informality is more prevalent have a larger number of children on average. Finally, we find no particular pattern for rural area. Controlling for all other factors, living in a rural area increases the probability of being formal in Colombia and Ecuador, it decreases it in Peru and Venezuela, and it is not significant in Bolivia.

\subsubsection{Budgetary implications of transitions to formal employment}

Based on the coefficients estimated in Table 6, we predict the probability of being formal for our sample of informal workers under analysis. We then select the 10 percent with the highest probability of being formal and create groups, adding the next 10 percent of informal workers with the highest probability of being formal, until we cover the whole informal population. ${ }^{18}$ As expected, those with the highest probability of being formal have, on average, higher education levels and earnings.

\footnotetext{
${ }^{18}$ See Table 14 in the Appendix for the characteristics of the 10 percent with the highest probability of being formal.
} 


\section{Bolivia}

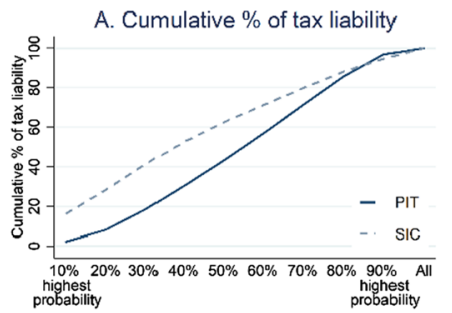

B. Cumulative $\%$ of tax payers

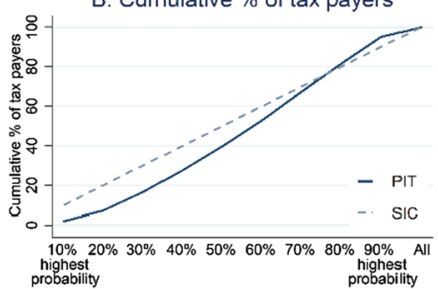

Colombia

A. Cumulative $\%$ of tax liability
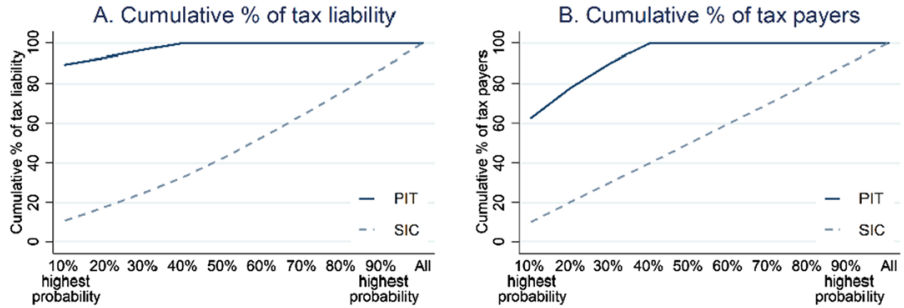

Ecuador
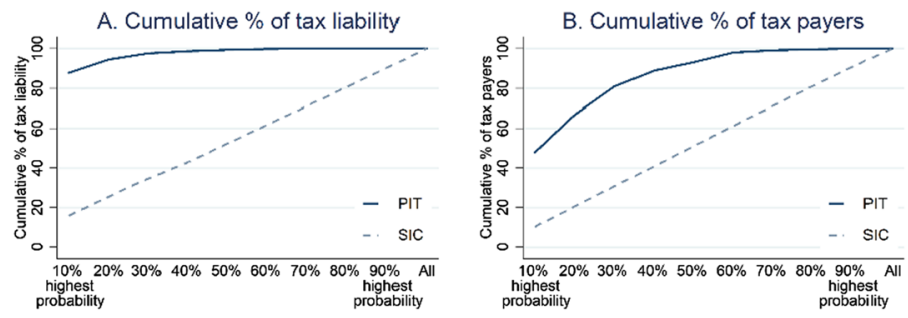

Peru

A. Cumulative $\%$ of tax liability
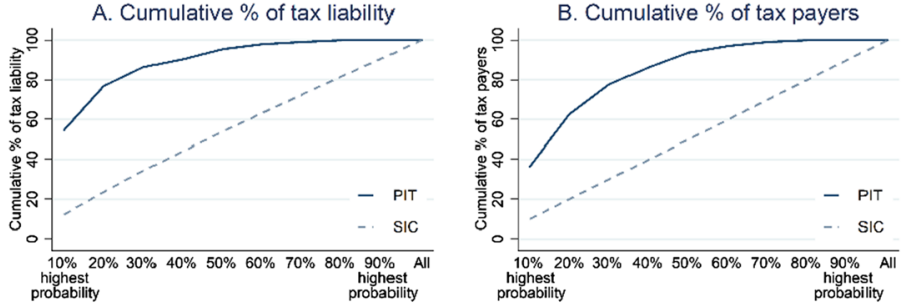

Venezuela
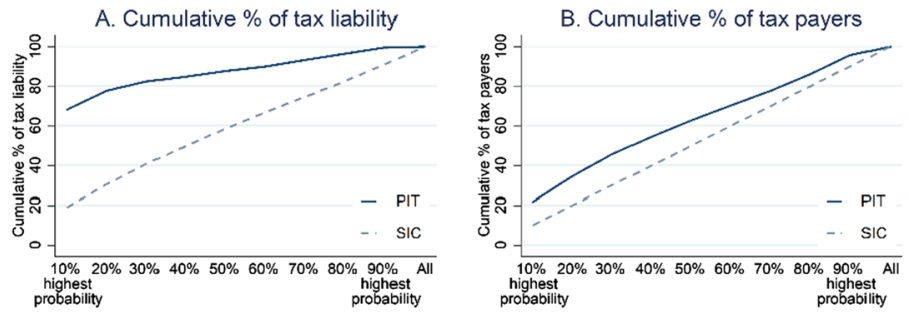

Fig. 6 Cumulative percentage of additional tax liability and additional taxpayers by probability of being formal. Source Authors' calculations based on microsimulation models 
Table 7 and Fig. 6 present the results of our simulations. Table 7 presents tax revenue under the baseline scenario (official statistics) and additional tax revenue under our counterfactual where our whole sample of informal workers would enter formal employment. Panel A in Fig. 6 presents the simulated cumulative percentage of additional tax liability, starting from individuals with the highest probability of being formal until the whole sample of informal workers is covered. Results distinguish between personal income tax and social insurance contributions, as the pattern differs between these two instruments.

In terms of personal income tax, our counterfactual of a fully formalized economy would have varying effects across countries. In Bolivia and Venezuela, personal income tax revenue as a percent of GDP would more than double, from 0.22 to 0.77 percent ( 0.55 percentage points increase) and 0.80 to 2.1 percent ( 1.3 percentage points increase), respectively. The effect of a fully formalized labor force would be the smallest in Colombia, representing a 2.5 percent increase in personal income tax revenue with respect to the baseline scenario. In Ecuador and Peru, the effect would also be limited with an increase in personal income tax revenue of 15.5 percent and 7 percent, respectively.

Note that although the literature usually refers to informality as a barrier to increase fiscal capacity, our results show that this seems to be the case in Bolivia and Venezuela, but to a much lesser extent in Colombia, Ecuador, and Peru. Moreover, the potential tax revenue from personal income tax under a fully formalized economy remains low compared to tax revenue collected currently from this source in OECD countries, which represented on average 8.3 percent of GDP in 2015 (OECD, 2020). As discussed before, the high exempted thresholds and the presence of generous tax deductions - and in the case of Bolivia, the little progressivity and collection capacity of personal income tax-limit the potential to increase fiscal capacity as a result of entries to formal employment. Moreover, it is important to bear in mind that our analysis considers full tax compliance of informal workers upon entry to formal employment, meaning that they would declare the totality of their earnings for the calculation of personal income tax. However, tax avoidance and tax evasion are prevalent in the region, so the potential additional tax revenue under a fully formalized labor force might be lower if the possibility of avoiding or evading taxes was considered.

Figure 6 shows that in all countries except Bolivia, a transition of the 10 percent with the highest probability of being formal would be enough to capture a large share of the additional personal income tax potential liability. In Colombia and Ecuador, over 80 percent of the additional personal income tax liability would be captured following a transition of the 10 percent with the highest probability of being formal. In Peru and Venezuela, the share of personal income tax liability captured by those with the highest probability would amount to 54.6 and 68 percent, respectively. In Bolivia, the pattern of the cumulative tax liability differs namely because of the design of personal income tax, which is proportional with a rate of 13 percent for salaried employees and 15.5 percent for the self-employed workers.

In terms of social insurance contributions, Bolivia, Peru, and Venezuela would see their revenue more than double under a fully formalized economy (Table 7). The effect would also be large in Ecuador, where social insurance contributions revenue 
Table 8 Additional number of taxpayers (in \% of active population). Source Authors' calculations based on microsimulation models

\begin{tabular}{lcccrl}
\hline & Bolivia & Colombia & Ecuador & Peru & Venezuela \\
\hline PIT & 23.20 & 0.34 & 0.89 & 2.47 & 14.50 \\
$\begin{array}{l}\text { Social insur- } \\
\text { ance contri- } \\
\text { butions }\end{array}$ & 39.92 & 39.75 & 36.50 & 42.85 & 40.58 \\
& & & & & \\
\hline
\end{tabular}

would increase by 79 percent. In Colombia, however, the effect would be smaller, representing an increase of 23 percent of social insurance contributions revenue. The pattern of the cumulative social insurance contributions liability by probability of being formal is similar in all countries (Panel A in Fig. 6), given that in all countries social insurance contributions are proportional to income. The share of the additional social insurance contributions revenues captured by those with the highest probability of being formal would range between 10 percent in Colombia and 20 percent in Venezuela.

Table 8 and Panel B in Fig. 6 show the results of our simulations in terms of additional number of taxpayers. Under a fully formalized economy, the additional number of personal income tax payers would be the highest in Bolivia and Venezuela, representing 23.2 percent and 14.5 percent of the active population, respectively. The increase would be smaller in Colombia, Ecuador, and Peru, representing 0.34, 0.89 , and 2.47 percent of the active population, respectively. The effect would be much larger in terms of social insurance contributions payers across countries, with the additional number of payers ranging between 36.5 (Ecuador) and 40.6 percent (Peru) of the active population. The pattern of cumulative number of taxpayers follows closely that of tax revenue (Fig. 6).

\subsubsection{Distributional implications of transitions to formal employment}

Figure 7 presents the effect of potential entries to formal employment on income inequality. The figure depicts the percentage change in the Gini coefficient by the probability of being formal, where the zero percent line represents the baseline Gini coefficient in each country in $2015 .{ }^{19}$

Our results show that an entry to formality of the 10 percent of informal workers with the highest probability of being formal would decrease inequality in all countries, although the decrease is small in Peru, where the Gini coefficient would remain broadly the same. The decrease on income inequality, as a result of this counterfactual transition, is driven by the fact that those with the highest probability of being formal are mainly high earners. Inequality drops as they enter formality, because this group of workers would start paying personal income tax (see effect on Fig. 6), which would improve the redistributive effect of the tax-benefit system.

\footnotetext{
${ }^{19}$ Bolivia: 48.4 percent, Colombia: 56.4 percent, Ecuador: 46.4 percent, Peru: 48.2 percent, and Venezuela: 47.0 percent.
} 

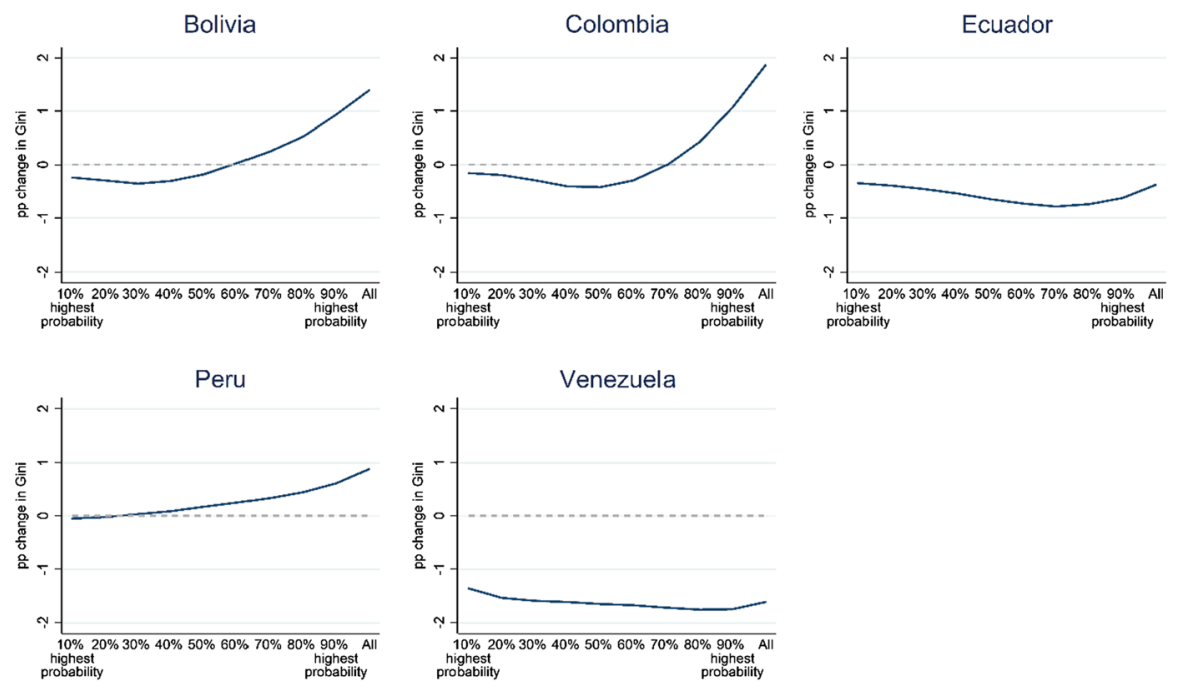

Fig. 7 Change in the Gini coefficient by probability of being formal (in percentage points). Source Authors' calculations based on microsimulation models. Note The dashed horizontal line corresponds to the baseline level of inequality measured by the Gini coefficient: Bolivia: 48.4 percent, Colombia: 56.4 percent, Ecuador: 46.4 percent, Peru: 48.2 percent, and Venezuela: 47.0 percent

Note, however, that the increased redistributive effect might be lower if the possibility of tax avoidance or tax evasion was taken into account.

As more individuals with a lower probability of being formal enter formality, income inequality starts increasing and surpasses the baseline Gini coefficient in 2015. In Colombia, the increase in income inequality under a fully formalized economy would be the largest, amounting to a 1.9 percentage points increase in the Gini coefficient (from 56.4 to 58.2 percent). The increase in income inequality as more informal workers (with a lower probability of being formal) enter formality is due to the fact that most self-employed informal workers are low earners and a move to formal employment would represent an additional cost in the form of social insurance contributions payments. As discussed in the previous section, the cost of entering formal employment (FTR) is the largest for the selfemployed and individuals at the bottom of the income distribution, meaning that inequality will increase, as self-employed workers with low earnings (which represent the majority of informal workers) would face social insurance contribution payments.

The only exceptions to the increasing pattern in inequality are Ecuador and Venezuela, where inequality would decrease even under the counterfactual of a fully formalized economy, although the decrease would still be larger for entries of groups with a higher probability of being formal. The contrasting pattern observed in Ecuador is explained by the fact that, contrary to other countries, the informal population is composed of a large share of employees who upon entry to formal employment are assumed to earn at least the minimum wage, which reduces income inequality. For Venezuela, the contrasting pattern is explained by the fact that the decrease in income inequality due to increased taxes paid by informal high earners (those with the highest probability) dominates the effect of increasing inequality due to social 

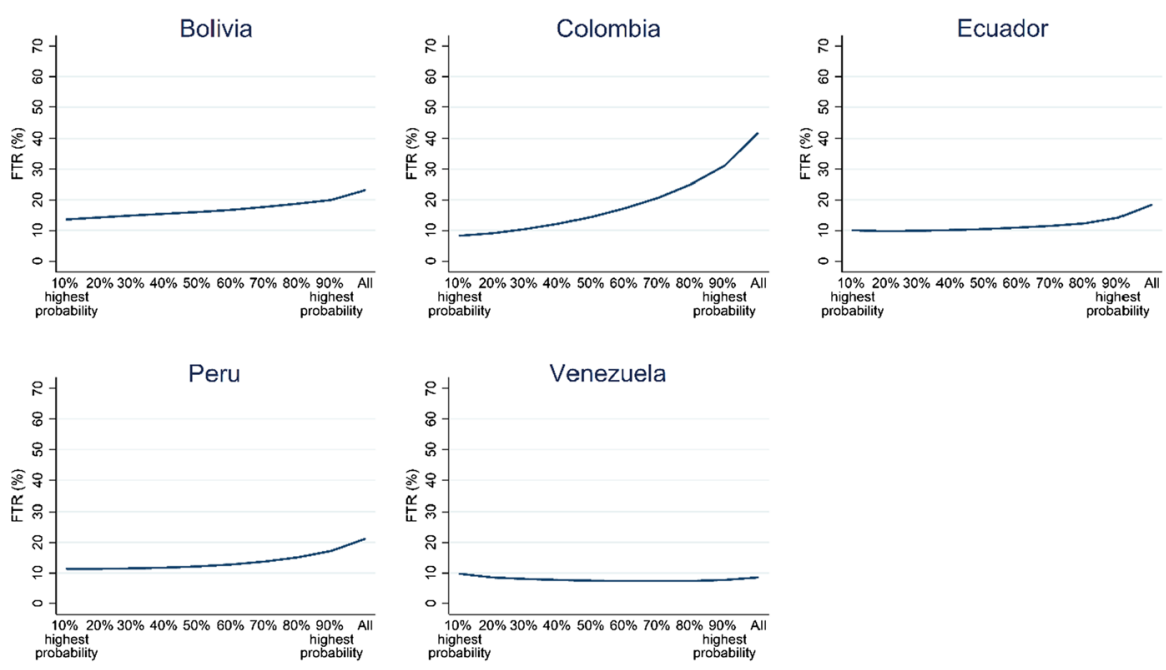

Fig. 8 Formalization tax rates by probability of being formal. Source Authors' calculations based on microsimulation models

insurance contribution payments of informal low earners. As seen earlier in Fig. 3, financial costs of entering formal employment are in general low for informal workers at the bottom of the income distribution in Venezuela. However, a point of caution has to be made regarding the impact of the macroeconomic distortions in prices and wages in Venezuela that made the income tax payments particularly high for the consolidated middle class and the rich, as mentioned previously.

To confirm the point made about the pattern of inequality by probability of being formal and the costs of entering formal employment, Fig. 8 presents the pattern of FTR by the probability of being formal. Our results show that the FTRs are low for informal workers with the highest probability of being formal (around 10 percent). In all countries except Venezuela, FTRs increase as the probability of being formal decreases. In Venezuela, FTRs are broadly similar for workers with different probabilities of being formal, which is in line with the pattern observed in terms of inequality. Although FTRs are low for the 10 percent of informal workers with the highest probability of being formal, in absolute terms the cost of formalization might be high for these workers as pointed out by the fact that a large share of the additional tax revenue would be captured upon their entry to formal employment.

To further highlight the link between informal employment and inequality, we replicate the analysis in this section but rather than using the predicted probability of being formal to formalize informal workers, we simulate the effect of transitions to formal employment based only on the level of earnings of informal workers (from higher to lower). Figure 12 in Appendix B presents the simulated cumulative percentage of additional tax and social insurance contribution liability (Panel A) and cumulative percentage of additional tax and social insurance contribution payers. Figure 13 in Appendix B presents the effect of potential entries to formal employment by earnings deciles on income inequality. 
Fig. 9 Distribution of FTR, hypothetical reform scenario. Source Authors' calculations based on microsimulation models. Note Countries are ordered by mean FTR

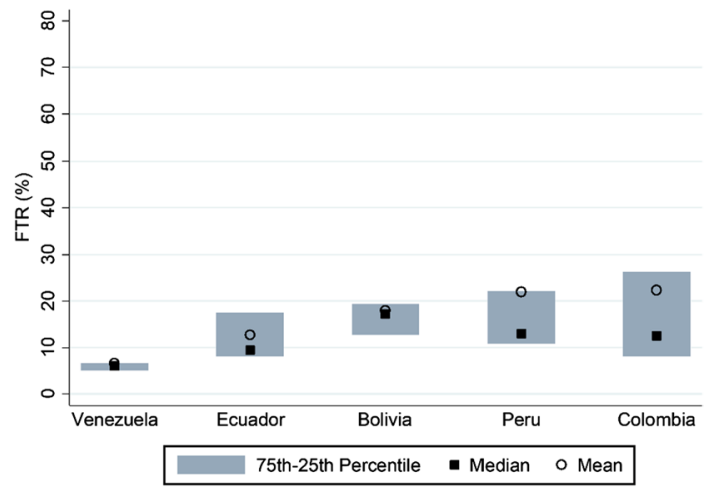

The results show that a potential entry of the 10 percent highest earning informal workers to formal employment would capture between 36 percent of the additional personal income tax revenue in Bolivia and up to 100 percent of the additional personal income tax revenue in Colombia. In Ecuador, Peru, and Venezuela, the proportion of the additional personal income tax captured by the formalization of the 10 percent highest informal earners would also be substantial, representing 99, 96.5, and 90.4 percent, respectively.

The distributional consequences of the formalization of the $10 \%$ highest earning informal workers would also be important. The Gini coefficient would drop between 0.18 percentage points in Peru to 1.76 percentage points in Venezuela. Note that inequality starts increasing (compared to the situation when only the 10 percent highest informal earners are formalized) as more informal workers with lower earnings would enter formal employment, however, a slight decrease in inequality is observed once the bottom of the informal earnings distribution has been formalized. This is explained by the fact that earnings of informal employees below the minimum wage have been raised to the level of the minimum wage upon formalization.

\subsection{Reducing financial disincentives to formal employment: a hypothetical reform}

The results of the previous sections show that informal workers with low earnings have a lower probability of being formal and face higher financial disincentives to enter formal employment. As previously discussed, high FTRs are mostly explained by the requirement that workers contribute at least on the basis of the minimum wage, which translates into a high cost of formalization for informal workers with low earnings (i.e., below the minimum wage). In this section, we therefore analyze the effects of a counterfactual policy reform in which the minimum contribution base is reduced to half of the minimum wage in all countries. The choice of this counterfactual is motivated by the fact that a large share of workers in informal employment have earnings below the minimum wage, in particular the self-employed.

Figure 9 shows the distribution of FTR under our counterfactual scenario. Our results show a decrease in FTRs in all countries under our hypothetical reforms. 


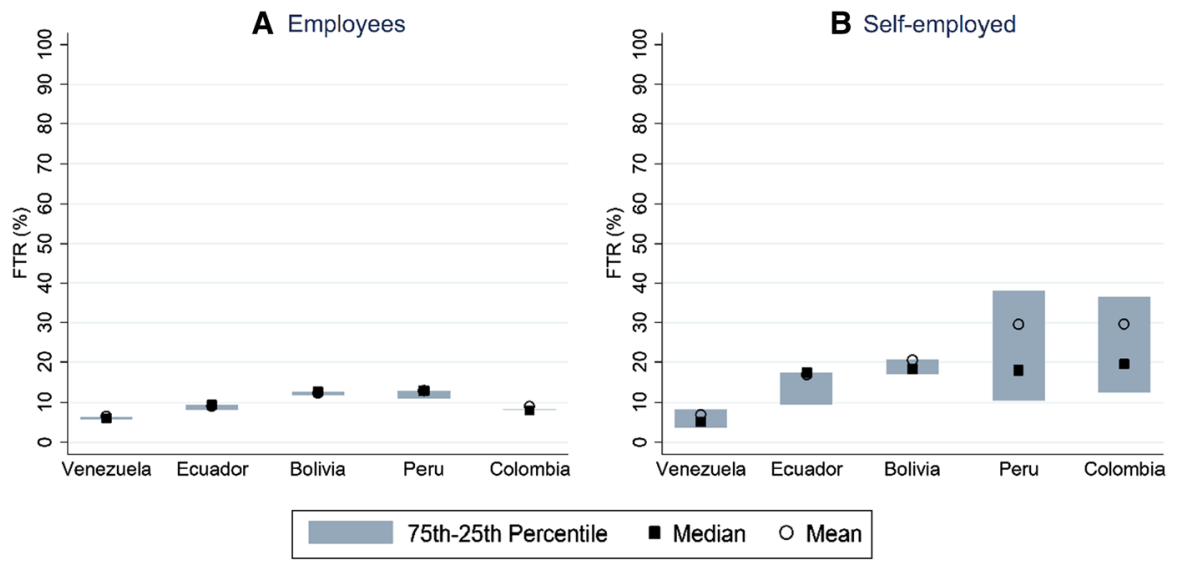

Fig. 10 Distribution of FTR by employment status, hypothetical reform scenario. Source Authors' calculations based on microsimulation models. Note Countries are ordered by mean FTR of the self-employed

Colombia would experience the largest reduction in average FTR of 47 percent (42-22.3 percent). The decrease would also be important in Ecuador (18.3-12.7 percent), Bolivia (23.1-17.9 percent), and to a lesser extent Venezuela (8.5-6.6 percent). Peru would experience the smallest drop in FTR, of 8 percent (23.8-22 percent) because the reform affects only employees, for whom the minimum wage serves as basis for the minimum contribution base, whereas self-employed workers pay fixed contribution amounts for health insurance depending on age. In addition, the reform would also reduce the variation of FTRs, depicted by the inter-quartile range, particularly in Colombia.

Figure 10 shows the distribution of FTR by employment status under our counterfactual scenario. The largest decrease in financial disincentives to formal employment is observed for the self-employed, who have in general lower earnings than their salaried counterparts and incur higher formalization costs due to the requirement of contributing at least on the basis of the minimum wage. Colombia would experience the largest reduction in average FTR for the self-employed, from 57.9 to 29.7 percent, followed by Venezuela with a drop in FTR for the self-employed of 43 percent (12.1-6.9 percent). The decrease in FTR would also be important in Ecuador (26.1-16.9 percent) and to a lesser extent in Bolivia (27.1-20.5). Selfemployed workers in Peru would experience no change in their FTR as social insurance contributions are set as fixed amounts depending on age. The decrease in FTRs for employees is less sizeable in all countries ranging from a 10 percent decrease in Venezuela to a 30 percent decrease in Colombia. 


\section{Conclusions}

Informality is deeply rooted in the economic systems of LAC countries, and the Andean countries discussed herein are not the exception. Working at the margin of the tax and social security systems compromises fiscal resources, which some countries urgently need. More importantly, however, it puts a limit on long-term growth and the perspectives of achieving convergence to more developed economies. Despite the governments' efforts to tackle both workers and firm informality, this phenomenon still accounts for two-thirds of the workforce and roughly half of the firms, although information on the latter is scarce.

In this paper, we attempt to make a contribution to the literature by examining the incentives that workers have to work formally or informally. More precisely, we use harmonized microsimulations models based on the information provided in official household surveys to construct indicators of financial (dis)incentives to formality implied by the design of the tax-benefit systems in Bolivia, Colombia, Ecuador, Peru, and Venezuela. Our indicators of FTRs capture the percentage of earnings in informality that would be lost due to increased social insurance contributions and income tax payments or benefit withdrawal upon entry to formal employment.

Our analysis provides a number of interesting results. First, we find that financial disincentives to formal employment are higher and more volatile among selfemployed workers, whereas salaried employees show lower and more stable formalization costs, which might make them more likely to make the transition to formality, especially those working in medium-sized and large firms. The higher FTRs of selfemployed workers, compared to their salaried counterparts, are explained by higher social insurance contribution rates applied to this group, and in particular by the requirement of paying social insurance contributions at least on the basis of the minimum wage, whereas self-employed workers belong to a broader spectrum of the income distribution, with many of them earning very low income, making formalization not financially viable.

Our results also show that the fiscal capacity of governments would improve following the potential entry of newly formalized workers who would start contributing to social security. On the other hand, given the generous design of the personal income tax systems in the Andean region, we estimate that its contribution to the fiscal space would only be marginal, even in a scenario of a fully formalized labor force. Interestingly, a potential formalization of the 10 percent of informal workers with the highest probability of becoming formal would harvest important fiscal gains, allowing to capture a substantial share of the additional tax revenue lost due to informality, with positive impacts on inequality reduction. FTRs for the 10 percent of informal workers with the highest probability of being formal are low. However, the fact that their potential formalization would capture a large share of additional tax revenue might reflect that they face high costs of formalization in absolute terms.

In terms of economic policy, there are several ways to achieve the formalization targets resulting from the simulations, ranging from making formality more attractive for workers and firms, designing audit strategies to reduce informality within formal firms, and training workers to improve labor productivity. Naturally, higher 
formalization rates might imply greater labor costs, which can induce behavioral changes of workers and firms. Thus, in implementing formalization strategies, governments need to evaluate these potential fiscal gains against increased hiring costs for the firms. In any case, there is ample evidence that formalization has positive effects in terms of salaries, social protection, productivity, and long-term growth (IDB, 2010; Carpio \& Pagés, 2009; La Porta \& Schleifer, 2008; Santa María \& Rozo, 2008). The comparative perspective herein provides insights into strategies that Andean governments could adopt to reduce the financial burden to formalization of certain population groups. For instance, the Seguro Campesino in Ecuador offers social insurance coverage to self-employed workers in rural areas, with lower contribution rates than their counterparts in the general regime. Similar schemes could be implemented to target different categories of self-employed workers in the region, with the aim of reducing their financial disincentives to enter formal employment.

There are some avenues for further research related to the methodological caveats of our study. One consists of revising the assumption that earnings in informality remains the same upon entry into formal employment. Likely, the income perceived by employees in formality would be at least the minimum wage in the case of lower earners, and other informal workers might experience a change in earnings in the event of entering formal employment (Jara \& Rodriguez, 2019). Incorporating changes in earnings to measure financial disincentives to formal employment requires rethinking the definition of FTR, and developing a method to disentangle the effect of changes in earnings from the effect of the design of the tax-benefit systems in the FTR indicator. Moreover, our analysis has looked at FTRs only from the perspective of workers, assuming that the cost of payroll taxes is fully absorbed by employers. However, increased costs for employers might reduce wages, which would need to be factored into the cost of formalization of workers. It is also important to stress that our analysis focuses on the financial disincentives to formal employment implied by the tax-benefit system. However, the decision to enter formal employment is also affected by other factors. In particular, some categories of workers (e.g., low-productivity workers) might be limited in the job opportunities available for them, pointing to the need to further analyze this issue from the perspective of a labor supply model with demand-side constraints. Finally, we have examined financial incentives to formal employment from a short-term perspective in which social insurance contributions are considered as a cost. However, within a dynamic setting, it would be useful to study the future benefits of formalization (e.g., access to contributory old-age pensions). Related to this, an increase in formal employment might imply higher expenditures in terms of health coverage and public pension payments. In this sense, the long-term sustainability of the welfare system should be considered in parallel with the need to increase fiscal capacity in the region. All of these extensions represent promising directions for future research.

\section{Appendix A: Tax-benefit microsimulation models for Latin America}

Our analysis relies on a novel set of tax-benefit microsimulation models for Latin American countries: COLMOD for Colombia, ECUAMOD for Ecuador, PERUMOD for Peru, and LATINMOD for Bolivia and Venezuela. In a nutshell, 
tax-benefit microsimulation models represent a series of arithmetic equations which are applied to representative household surveys to compute taxes and social contribution paid, and benefits received by each household in the data depending on its income and demographic characteristics. All income concepts and sociodemographic characteristics in the surveys have been harmonized, and the models have been implemented in the EUROMOD software (Sutherland \& Figari, 2013), following the same conventions for the simulation of taxes, social insurance contributions and benefits, to ensure cross-country comparability.

More formally, let the vector $z$ denote labor market and sociodemographic characteristics of a given household, including information about affiliation to social security, and the vector $x$ denote household market income. ${ }^{20}$ Household market income is made of earnings (from employment and self-employment), capital income, income from property rent, etc., which are reported separately in the data. For completeness, let $x_{w}$ denote earnings and $x_{-w}$ denote other components of market income.

Household disposable income, $y$, is given by.

$y(z, x, p)=x+d(z, x, p)$, where $d(z, x, p)$ is a compositive arithmetic function representing the sum of benefits received (positive values) and social insurance contributions and taxes paid (negative values) by the household, and $p$ is a set of parameters of the tax-benefit system (e.g., benefit amounts, minimum thresholds for social insurance contributions, level of tax bands, etc.). Each tax-benefit instrument (i.e., social insurance contributions, taxes and benefits) is calculated according to the policy rules in place in each country, taking into account potential interactions between the different instruments (e.g., social insurance contributions usually need to be calculated first to deduct them from earnings to derive taxable income for the purposes of personal income tax simulations).

Tax-benefit microsimulation models allow us to simulate counterfactual distributions of household disposable income by changing the labor market, sociodemographic characteristics $(z)$ or household market income in the data $(x)$, or the parameters of the tax-benefit system $(p)$. In our analysis, affiliation to social security is imposed to workers in informal employment, which is represented by a modified vector $z^{\prime}$, resulting in a counterfactual distribution of disposable income:

$y^{\prime}\left(z^{\prime}, x, p\right)=x+d^{\prime}\left(z^{\prime}, x, p\right)$,

The original distribution, $y$, and the counterfactual distribution $y^{\prime}$ are then used to assess the financial disincentives to enter formal work for each informal worker to whom affiliation to social security was imposed, following Eq. (1) in Sect. 3.2.

Scope of the simulations In all countries under analysis, the main policy components of disposable income have been simulated, including employee and selfemployed social insurance contributions, personal income tax, and the main cash transfer programs of each country. The following cash transfers have been simulated in the models: Bono Juancito Pinto, Bono Juana Azurduy and Renta Dignidad in Bolivia; Familias en acción and Colombia Mayor in Colombia; Bono de Desarrollo Humano and Bono Joaquín Gallegos Lara in Ecuador; Juntos in Peru; Misiones educativas: Robinson (I y II), Ribas y Sucre and Gran Misión en Amor Mayor

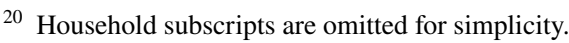


Venezuela in Venezuela. All these cash transfer programs are characterized by being proxy means-tested, meaning that eligibility to receive the benefit is assessed based on a composite welfare index (e.g., based on characteristics of the dwelling and the household) rather than household income. For this reason, potential transitions to formal employment do not automatically result in benefit withdrawals.

Tables 9, 10, 11 summarize the main parameters of simulated employee and self-employed social insurance contributions and personal income tax. We focus on the design of these three policy instruments as they play a role in the financial cost informal workers would incur upon entry to formal employment.

In terms of employee social insurance contributions (Table 9), there is a large variation in contribution rates from 6 percent in Venezuela to 12.71 percent plus an additional 10 percent on income above 21 minimum wages in Bolivia. In all countries, formal employees need to pay social insurance contributions at least on the basis of the minimum wage, whereas maximum levels of payment (i.e., ceiling) exist only in Colombia and Venezuela. Finally, employee social insurance contributions are deducted from labor income for the purpose of personal income tax payments in Bolivia, Colombia, and Ecuador.

In terms of self-employed social insurance contributions (Table 10), contribution rates vary between 13 percent and 30.5 percent in Bolivia, Colombia, Ecuador, and Venezuela. In Peru, fixed amounts between 0.18 and 0.29 times the minimum wage depending on age apply to health insurance contributions. In all countries except Peru, formal self-employed need to pay social insurance contributions at least on the basis of the minimum wage, whereas maximum levels of payment (i.e., ceiling) exist only in Colombia and Venezuela. Finally, self-employed social insurance contributions are deducted from labor income for the purpose of personal income tax payments in Bolivia, Colombia, and Ecuador.

In terms of personal income tax, in all countries individual taxation applies with the option of joint taxation in Venezuela. The level of the exempted threshold (i.e., lowest tax band limit) varies from 1.8 (Venezuela) to 4 (Colombia) annualized minimum wages. A larger variation is observed in terms of the threshold for the highest tax band, which reaches 7.1 (Venezuela) and 25.9 (Ecuador) annualized minimum wages. The highest tax rates are broadly similar across countries, ranging from 30 percent in Peru to 35 percent in Ecuador. Finally, it is worth noting that the number of tax deductions available in the design of personal income tax is mostly composed of expenditures in education, health, and housing. In Bolivia, personal income tax is part of the Régimen Complementario del Impuesto al Valor Agregado (RC-IVA), which allows the value added tax (VAT) paid on purchases to be deducted from the income tax liability, and a unique tax rate of 13 percent applies.

Validation Simulation results for the models used in the analysis have been validated against official statistics. The validation consists in comparing the aggregate number of recipients of simulated benefits and payers of simulated taxes and contributions, as well as the aggregate annual expenditure in social benefits and revenue from taxes and social insurance contributions, with external benchmarks. For validation results for Ecuador see Jara et al. (2019), for Colombia see Rodriguez et al. (2019), for Bolivia and Venezuela see Arancibia et al. (2019), and for Peru see Torres and Chang (2021). 


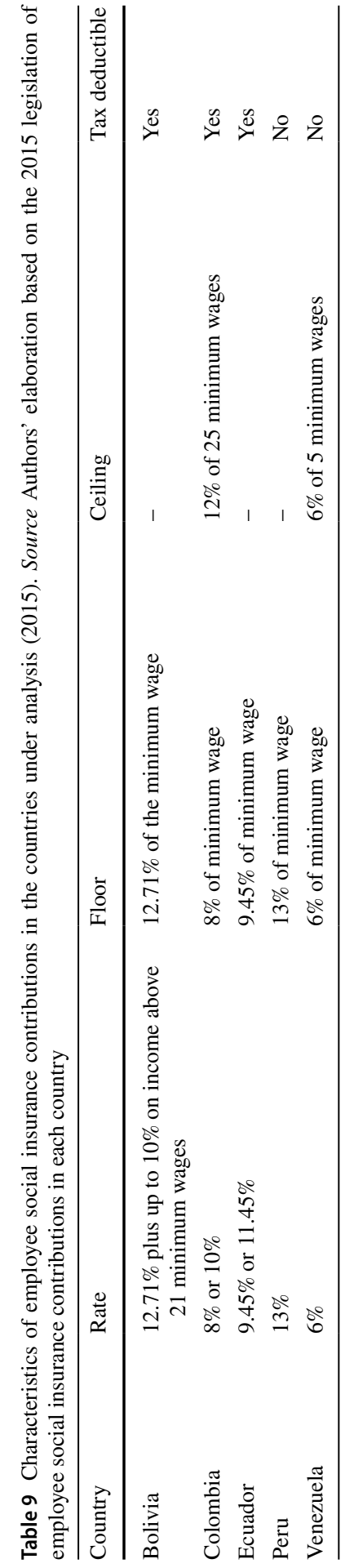


Table 10 Characteristics of self-employed social insurance contributions in the countries under analysis (2015). Source Authors' elaboration based on the 2015 legislation of self-employed social insurance contributions in each country

\begin{tabular}{|c|c|c|c|c|}
\hline Country & Rate & Floor & Ceiling & Tax deductible \\
\hline Bolivia & $\begin{array}{l}14.42 \% \text { plus up to } \\
10 \% \text { on income } \\
\text { above } 21 \text { minimum } \\
\text { wages }\end{array}$ & $\begin{array}{l}14.42 \% \text { of the minimum } \\
\text { wage }\end{array}$ & - & Yes \\
\hline Colombia & $28.5 \%$ or $30.5 \%$ & $28.5 \%$ of minimum wage & $\begin{array}{l}30.5 \% \text { of } 25 \text { minimum } \\
\text { wages }\end{array}$ & Yes \\
\hline Ecuador & $20.5 \%$ & $20.5 \%$ of minimum wage & - & Yes \\
\hline Peru & $\begin{array}{l}\text { Fixed amounts } \\
\text { between } 0.18 \text { and } \\
0.29 \text { times the } \\
\text { minimum wage }\end{array}$ & $\begin{array}{l}0.18 \text { times the minimum } \\
\text { wage }\end{array}$ & $\begin{array}{l}0.29 \text { times the minimum } \\
\text { wage }\end{array}$ & No \\
\hline Venezuela & $13 \%$ & $\begin{array}{l}13 \% \text { of the minimum } \\
\text { wage }\end{array}$ & - & No \\
\hline
\end{tabular}




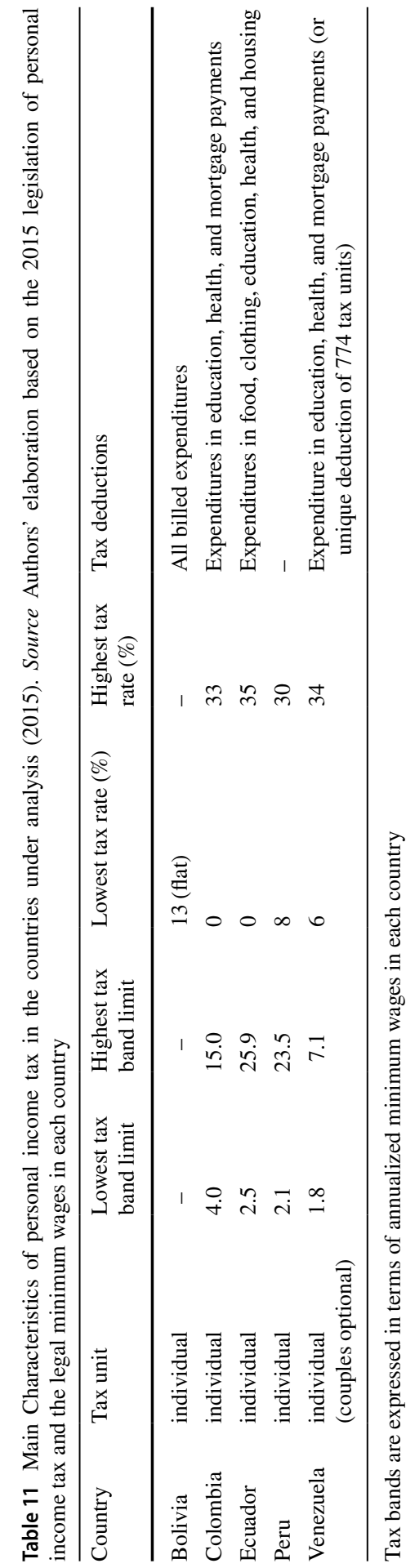




\section{Appendix B: Tables and figures}

See Tables 12, 13 and 14.

Table 12 Descriptive statistics of the selected sample of workers in informal employment. Source Authors' calculations based on microsimulation models

\begin{tabular}{llllll}
\hline & Bolivia & Colombia & Ecuador & Peru & Venezuela \\
\hline Population (unweighted) & 7165 & 14,498 & 28,830 & 28,274 & 30,273 \\
Population (weighted, in thousands) & 2026 & 9608 & 2835 & 7069 & 5745 \\
\% female & 34.1 & 37.2 & 37.2 & 42.2 & 37.9 \\
\% age (<30) & 27.3 & 28.0 & 29.5 & 26.8 & 29.5 \\
\% age (30-50) & 55.9 & 55.4 & 54.7 & 54.5 & 56.7 \\
\% age (50+) & 16.8 & 16.6 & 15.8 & 18.7 & 13.8 \\
\% low-skilled & 39.8 & 37.0 & 46.9 & 13.8 & 40.4 \\
\% medium-skilled & 50.8 & 52.8 & 41.3 & 85.9 & 49.7 \\
\% high-skilled & 9.4 & 10.2 & 11.8 & 0.3 & 9.9 \\
\% self-employed & 69.6 & 64.6 & 40.2 & 55.6 & 25.9 \\
\% rural & 31.1 & 24.9 & 31.6 & 18.9 & 6.2 \\
\% earning Q1 & 17.8 & 19.8 & 17.9 & 14.5 & 24.4 \\
\% earning Q2 & 25.2 & 33.3 & 29.2 & 28.3 & 24.3 \\
\% earning Q3 & 22.2 & 23.5 & 22.8 & 25.9 & 18.1 \\
\% earning Q4 & 20.0 & 13.6 & 18.4 & 20.7 & 15.6 \\
\% earning Q5 & 14.8 & 9.8 & 11.7 & 10.6 & 17.7 \\
\hline
\end{tabular}

The table reports the characteristics of the sample of informal workers in each country under analysis (e.g., \% of female, $\%$ of self-employed, etc.) 
Table 13 Income thresholds for socio-economic categories, 2015 (in local currency units at current prices). Source Authors' elaboration based on IDB (2020)

\begin{tabular}{|c|c|c|c|c|}
\hline & Poor & Vulnerable middle class & Consolidated middle class & Rich \\
\hline Bolivia & $<533.3$ & $533.3-1333.2$ & $1333.2-6665.9$ & $>6,665.9$ \\
\hline Colombia & $<205,329.7$ & $205,329.7-513,324.2$ & $513,324.2-2,566,620.8$ & $>2,566,620.8$ \\
\hline Ecuador & $<96.0$ & $96.0-240.0$ & $240.0-1200.0$ & $>1200.0$ \\
\hline Peru & $<269.6$ & $269.6-674.0$ & $674.0-3370.1$ & $>3370.1$ \\
\hline Venezuela & $<2546.2$ & $2546.2-6365.6$ & $6365.6-31,828.0$ & $>31,828.0$ \\
\hline
\end{tabular}

This classification follows the international lines of the World Bank for extreme poverty and its multiples (1.6, 4, and 20 times, respectively). A household belongs to the vulnerable middle class if it lives with an income between US\$5 and US\$12.4 per day; and the consolidated middle class corresponds to a range of income between US\$12.4 and US\$62 per day. The definition of the thresholds that separate the vulnerable middle class from the consolidated middle class is based on the concept of economic security. According to Duryea and Robles (2017), the probability of falling back into poverty increases for incomes below US\$12.4 per day, which supports the use of this threshold. The threshold of US\$62 is supported by several studies and exercises that define socio-economic status based on self-reported information

Table 14 Descriptive statistics of 10 percent of workers in informal employment with the highest probability of being formal. Source Authors' calculations based on microsimulation models

\begin{tabular}{llllll}
\hline & Bolivia & Colombia & Ecuador & Peru & Venezuela \\
\hline Population (unweighted) & 743 & 1044 & 2857 & 2020 & 2840 \\
Population (weighted, in thousands) & 203 & 961 & 283 & 707 & 575 \\
\% female & 34.8 & 42.8 & 40.1 & 49.6 & 56.1 \\
\% age (<30) & 33.5 & 30.6 & 29.9 & 27.2 & 18.9 \\
\% age (30-50) & 56.3 & 58.3 & 55.1 & 56.1 & 63.3 \\
\% age (50+) & 10.2 & 11.1 & 15.0 & 16.7 & 17.8 \\
\% low-skilled & 10.4 & 2.3 & 15.0 & 0.2 & 2.6 \\
\% medium-skilled & 51.8 & 61.3 & 43.5 & 97.6 & 54.8 \\
\% high-skilled & 37.8 & 36.5 & 41.6 & 2.2 & 42.6 \\
\% self-employed & 11.7 & 11.4 & 8.5 & 28.1 & 0.1 \\
\% rural & 14.9 & 5.7 & 27.2 & 0.7 & 0.6 \\
\% earning Q1 & 2.8 & 0.0 & 1.1 & 0.3 & 1.3 \\
\% earning Q2 & 23.0 & 3.9 & 14.2 & 10.3 & 6.3 \\
\% earning Q3 & 31.2 & 24.8 & 25.0 & 27.5 & 12.0 \\
\% earning Q4 & 23.4 & 34.5 & 26.8 & 31.1 & 22.7 \\
\% earning Q5 & 19.6 & 36.8 & 32.9 & 30.8 & 57.8 \\
\hline
\end{tabular}


See Figs. 11, 12 and 13.

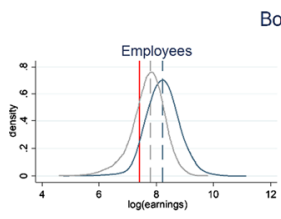

Bolivia

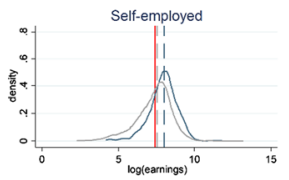

Ecuador
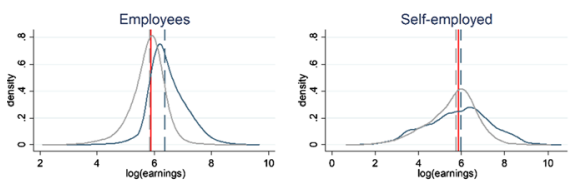

Venezuela

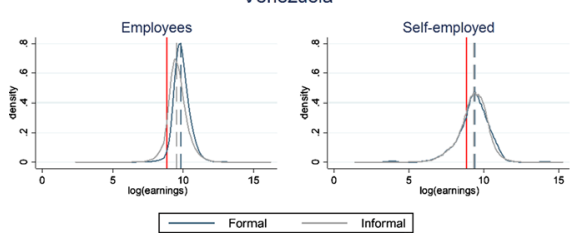

Colombia
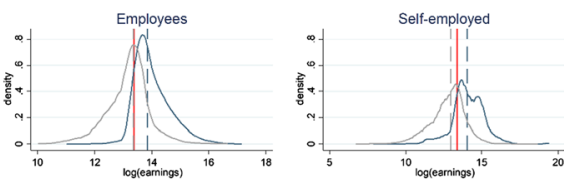

Peru
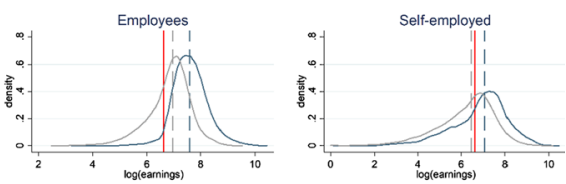

Fig. 11 Earnings distribution of formal and informal workers. Note Formal (informal) earnings distributions are depicted in blue (gray). Blue (gray) dashed vertical lines represent median earnings in formal (informal) employment. Red vertical lines represent minimum wages in each country. Sources Authors' calculations based on household surveys (Color figure online) 


\section{Bolivia}

A. Cumulative $\%$ of tax liability

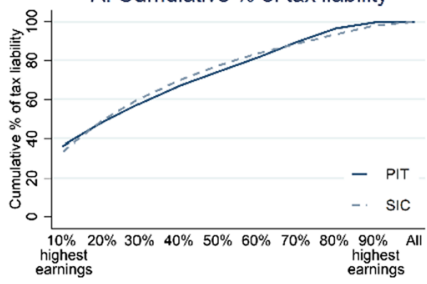

B. Cumulative $\%$ of tax payers

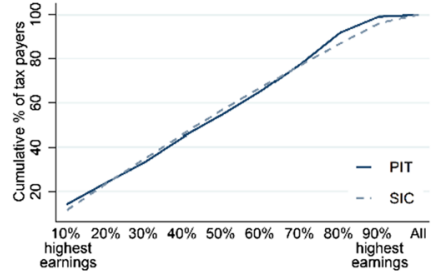

Colombia
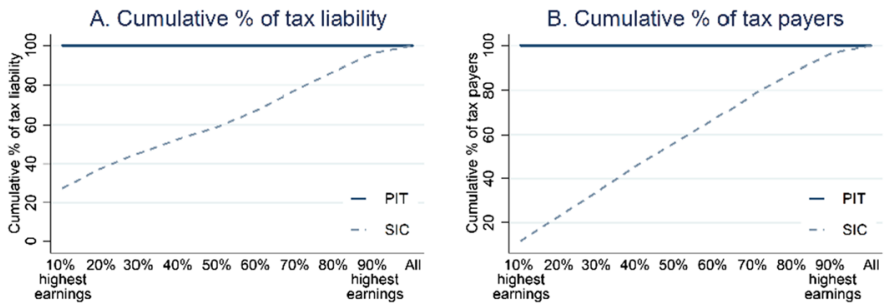

\section{Ecuador}

A. Cumulative $\%$ of tax liability

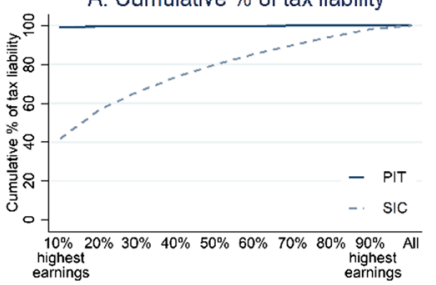

B. Cumulative $\%$ of tax payers

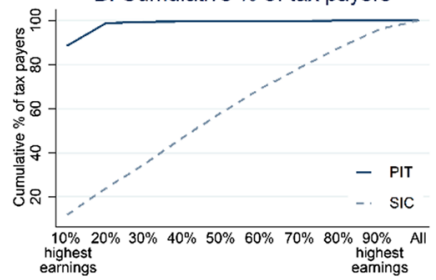

Peru

A. Cumulative $\%$ of tax liability

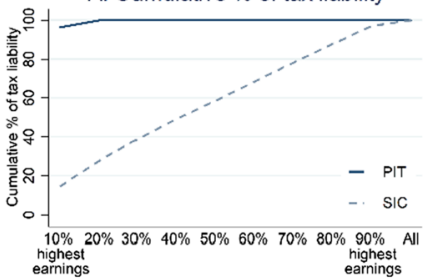

B. Cumulative $\%$ of tax payers

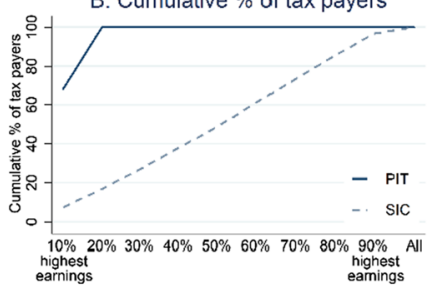

Venezuela

A. Cumulative $\%$ of tax liability

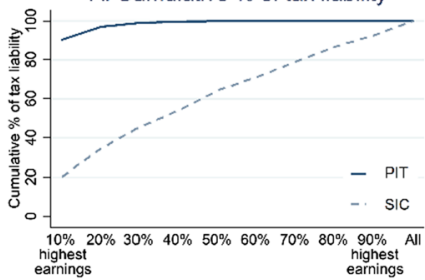

B. Cumulative $\%$ of tax payers

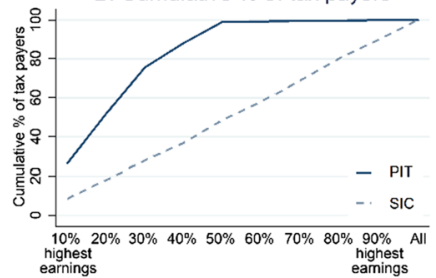


Fig. 12 Cumulative percentage of additional tax liability and additional taxpayers by earnings. Source Authors' calculations based on microsimulation models. Note Earnings deciles are based on earnings before the simulated transition to formal employment
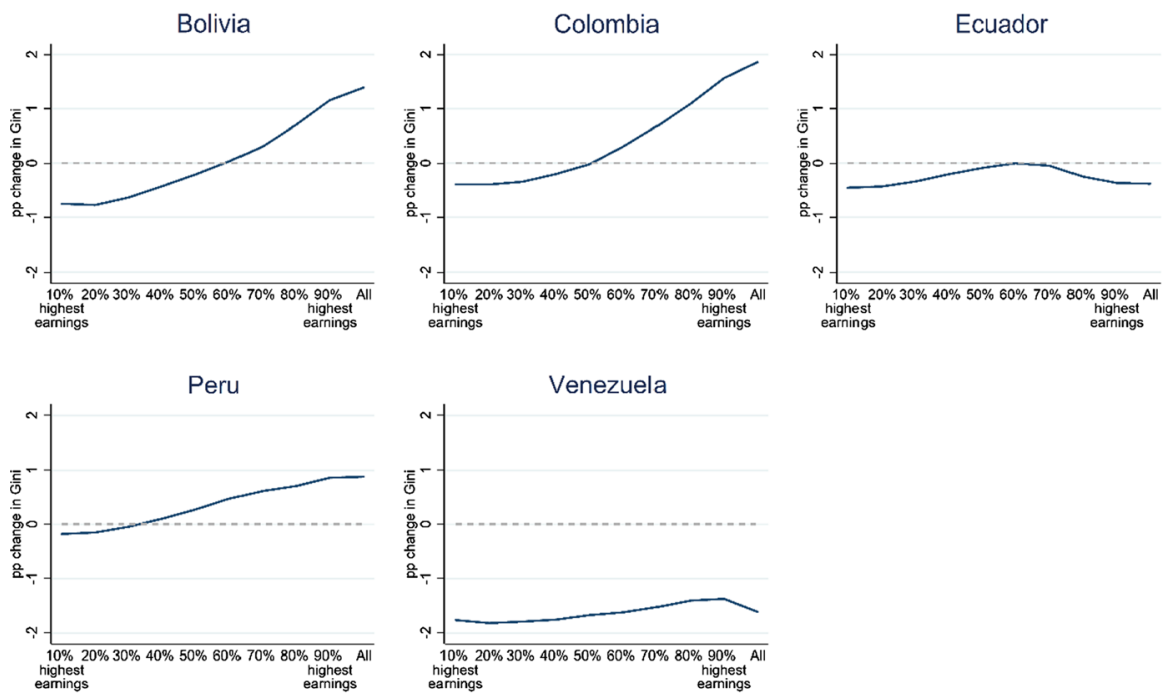

Fig. 13 Change in the Gini coefficient by earnings (in percentage points). Source Authors' calculations based on microsimulation models. Note The dashed horizontal line corresponds to the baseline level of inequality measured by the Gini coefficient: Bolivia: 48.4 percent, Colombia: 56.4 percent, Ecuador: 46.4 percent, Peru: 48.2 percent, and Venezuela: 47.0 percent). Earnings deciles are based on earnings before the simulated transition to formal employment

Acknowledgements The results presented herein are based on the following three projects: (i) LATINMOD, a project sponsored by the Centro Estratégico Latinoamericano de Geopolítica (CELAG), funded by The Venezuelan Economic and Social Development Bank (BANDES) and with the collaboration of EUROMOD; (ii) ECUAMOD v1.4. ECUAMOD is developed, maintained, and managed by UNUWIDER in collaboration with the EUROMOD team at the Institute for Social and Economic Research (ISER) the Southern African Social Policy Research Institute (SASPRI), and local partners in selected developing countries (Ethiopia, Ghana, Mozambique, Tanzania, Zambia, Ecuador and Viet Nam) in the scope of the SOUTHMOD project. The local partner for ECUAMOD is the Instituto de Altos Estudios Nacionales (IAEN); and (iii) COLMOD v1.2, a project developed and managed by the Faculty of Economics at Universidad Externado de Colombia. The authors are indebted to the many people who have contributed to the development of LATINMOD, SOUTHMOD, ECUAMOD, and COLMOD, as well as to David Rodriguez for his helpful assistance and comments. The results and their interpretation presented in this publication are solely the authors' responsibility.

\section{Declarations}

Conflict of interest The authors declare that they have no conflict of interest.

Open Access This article is licensed under a Creative Commons Attribution 4.0 International License, which permits use, sharing, adaptation, distribution and reproduction in any medium or format, as long as you give appropriate credit to the original author(s) and the source, provide a link to the Creative Commons licence, and indicate if changes were made. The images or other third party material in this article 
are included in the article's Creative Commons licence, unless indicated otherwise in a credit line to the material. If material is not included in the article's Creative Commons licence and your intended use is not permitted by statutory regulation or exceeds the permitted use, you will need to obtain permission directly from the copyright holder. To view a copy of this licence, visit http://creativecommons.org/licen ses/by/4.0/.

\section{References}

Alaimo, V., Bosch, M., Kaplan, D., Pagés, C., and Ripani, L. (2016). Jobs for growth. Washington, DC: Inter-American development bank. Available at: https://publications.iadb.org/en/jobs-growth.

Arancibia, C., Dondo, M., Jara, X. H., Macas, D., Oliva, N., Riella, R., Rodriguez, D., and Urraburu, J. (2019). Income redistribution in Latin America: A microsimulation approach. WIDER working paper 2019/1. Helsinki: UNU-WIDER.

Bosch, M., Melguizo, A., and Pagés, C. (2013). Better pensions, better jobs: Towards universal coverage in Latin America and the Caribbean. Washington, DC: Inter-American development bank. Available at: https://publications.iadb.org/en/publication/17407/better-pensions-better-jobs-towards-universalcoverage-latin-america-and.

Carpio, S., \& Pagés, C. (2009). Informality, productivity and resource misallocation in Brazil. Unpublished. Washington, DC: Inter-American Development Bank.

De Soto, H. (2000). The mystery of capital: Why capitalism triumphs in the west and fails everywhere else. NewYork: Basic Books.

Duryea, S., and Robles, M. (2017). Social pulse in Latin America and the Caribbean 2017: Family legacy, breaking the mold or repeating patterns? Washington, DC: Inter-American development bank. Available in: https://publications.iadb.org/en/social-pulse-latin-america-and-caribbean-2017-familylegacy-breaking-mold-or-repeating-patterns.

Gasparini, L., \& Tornarolli, L. (2009). Labor informality in Latin America and the Caribbean: Patterns and trends from household survey microdata. Revista Desarrollo y Sociedad, 63(1), 13-80.

Guerguil, M. (1988). Some thoughts on the definition of the informal sector. Cepal Review, 35, 57-65.

Harris, J. R., \& Todaro, M. P. (1970). Migration, unemployment, and development: A two-sector analysis. American Economic Review, 60(1), 126-142.

IDB (Inter-American Development Bank). (2020). Cómo impulsar el crecimiento y fortalecer la clase media en América Latina. Washington, DC: IDB.

IDB (Inter-American Development Bank). (2010). The age of productivity: Transforming economies from the bottom up. Washington, DC: IDB. Available at: https://publications.iadb.org/en/la-era-dela-productividad-como-transformar-las-economias-desde-sus-cimientos.

IDB (Inter-American Development Bank). (2013). Recaudar no basta: Los impuestos como instrumento de desarrollo. Washington, DC: IDB. Available at: https://publications.iadb.org/publications/spani sh/document/Recaudar-no-basta-Los-impuestos-como-instrumentode-desarrollo.pdf

IDB (Inter-American Development Bank). (2018). Creciendo con productividad: una agenda para la Región Andina. Washington, DC: IDB. Available at: https://publications.iadb.org/es/creciendo-conproductividad-una-agenda-para-la-region-andina.

ILO (International Labour Office). (1972). Employment, incomes and equality: A strategy for increasing productive employment in Kenya. Research paper. Geneva: ILO.

ILO (International Labour Office). (2014). Recent experiences of formalization in Latin America and the Caribbean. Notes on formalization. Geneva: ILO.

Jara, H. X., and Rodriguez, D. (2019). Financial disincentives to formal work: Evidence from Ecuador And Colombia. WIDER Working Paper 2019/14. Helsinki: UNU-WIDER.

Jara, H. X., Varela, M., Lee, P. C., and Montesdeoca, L. (2019). UNU-WIDER SOUTHMOD Country Report: ECUAMOD v1.4, 2011-2018. UNU-WIDER SOUTHMOD Country Report Series. Helsinki: UNU-WIDER.

Jara, H. X., \& Varela, M. (2019). Tax-benefit microsimulation and income redistribution in Ecuador. International Journal of Microsimulation, 12(1), 52-82.

Koettl, J. (2013). Does formal work pay in Serbia? The role of labor taxes and social benefit design in providing disincentives for formal work. In C. R. Laderchi \& S. Savastano (Eds.), Poverty and exclusion in the Western Balkans. New York, New York: Springer. 
Koettl, J., \& Weber, M. (2012). Does formal work pay? The role of labor taxation and social benefit design in the New EU member states. In S. W. Polachek \& K. Tatsiramos (Eds.), Informal employment in emerging and transition economies. Emerald Group Publishing: Bingley.

La Porta, R., \& Shleifer, A. (2008). The unofficial economy and economic development. Brookings Papers on Economic Activity, 2008, 275-352.

La Porta, R., \& Shleifer, A. (2014). Informality and development. Journal of Economic Perspectives, 28(3), 109-126.

Levy, S. (2008). Good intentions, bad outcomes: Social policy, informality, and economic growth in Mexico. Washington, DC: Brookings Institution Press.

Levy, S. (2018). Under-rewarded efforts: The elusive quest for prosperity in Mexico. Washington, DC: Inter-American development bank. Available at: https://flagships.iadb.org/en/Under-Rewarded-Effor ts.

Margolis, D. (2014). By choice and by necessity: Entrepreneurship and self-employment in the developing world. European Journal of Development Research, 26, 419-436. https://doi.org/10.1057/ejdr. 2014.25

OECD (Organization for Economic Cooperation and Development). (2020). Tax on Personal Income (indicator).https://doi.org/10.1787/76e12892-en. Accessed 15 May 2020.

OECD. (2021). Revenue statistics in Latin America and the Caribbean 2021. Paris: OECD Publishing.

OECD, Economic Commission for Latin America and the Caribbean (ECLAC), Inter-American Center of Tax Administrations (CIAT), and Inter-American Development Bank (IDB). (2017). Revenue statistics in Latin America and the Caribbean 1990-2015. Paris, France: OECD Publishing. Available at: https://publications.iadb.org/en/revenue-statistics-latin-america-and-caribbean-1990-2015.

Oliva, N. (2018). LATINMOD: Un microsimulador regional de políticas fiscales en América Latina. Caracas, Venezuela: Banco de Desarrollo Económico y Social de Venezuela (BANDES) and Centro Estratégico Latinoamericano de Geopolítica (CELAG).

Perry, G. E., Maloney, W. F., Arias, O., Fajnzylber, P., Mason, A., \& Saavedra-Chanduvi, J. (2007). Informality: Exit and exclusion. Washington, DC: World Bank.

Rauch, J. E. (1991). Modeling the informal sector formally. Journal of Development Economics, 35(1), 33-47.

Rodríguez, D. (2019). Política fiscal, pobreza y desigualdad: Un modelo de microsimulación para Colombia. Ensayos De Economía, 29(54), 53-88. https://doi.org/10.15446/ede.v29n54.76499

Rodríguez, D., Corredor, F., Culma, A., \& Martinez, P. (2019). COLMOD Country report Colombia. $1-45$.

Saavedra, J., \& Chong, A. (1999). Structural reform, institutions and earnings: Evidence from the formal and informal sectors in Urban Peru. Journal of Development Studies, 35, 95-116.

Salazar-Xirinachs, J. M., and Chacaltana, J. (2018). Políticas de formalización en América Latina: avances y desafíos. Lima, Peru: Organización Internacional del Trabajo. Available at https://www. ilo.org/wcmsp5/groups/public/---americas/---ro-lima/documents/publication/wcms_645159.pdf.

Santa María, M., and Rozo, S. (2008). Informalidad empresarial en Colombia: Alternativas para impulsar la productividad, el empleo y los ingresos. Documento de Trabajo de N. 40. Bogota, Colombia: Fedesarrollo. Available at: https://www.repository.fedesarrollo.org.co/handle/11445/1207.

Sutherland, H., \& Figari, P. (2013). EUROMOD: The European union tax-benefit microsimulation model. International Journal of Microsimulation, 1(6), 4-26.

Torres, J., \& Chang, R. (2021). PERUMOD Country Report Peru, Mimeo.

Weber, M. (2015). Measuring disincentives to formal work. IZA world of labor 213. Bonn, Germany: IZA institute of labor economics. Available at: https://wol.iza.org/uploads/articles/213/pdfs/measu ring-disincentives-to-formal-work.pdf.

Publisher's Note Springer Nature remains neutral with regard to jurisdictional claims in published maps and institutional affiliations. 